\title{
Serpentine mountain uplift in northern Japan triggered the divergence of a narrow endemic from a widespread (sub)arctic Asia-Alaska species complex of Lagotis (Plantaginaceae)
}

\author{
Atsushi Sugano ${ }^{1}$ - Tomoko Fukuda ${ }^{2} \cdot$ Yoshinori Murai $^{3}$ - Chernyagina Olga A ${ }^{4} \cdot$ \\ Suyama Yoshihisa ${ }^{5} \cdot$ Yoshihiro Tsunamoto $^{5} \cdot$ Hayato Tsuboi $^{6} \cdot$ Yoko Nishikawa $^{7}$ • \\ Takashi Shimamura $^{7} \cdot$ Hiroko Fujita $^{8} \cdot$ Koh Nakamura $^{8, *}$ \\ ${ }^{1}$ Division of Environmental Resources, Graduate School of Agriculture, Hokkaido \\ University, Sapporo 060-8589, Japan \\ ${ }^{2}$ College of Liberal Arts and Sciences, Mie university, Tsu 514-8507, Japan \\ ${ }^{3}$ Department of Botany, National Museum of Nature and Science, Tsukuba 305-0005, \\ Japan \\ ${ }^{4}$ Kamchatka Branch of the Pacific Institute of Geography, Far Eastern Branch of the \\ Russian Academy of Sciences, Petropavlovsk-Kamchatsky 683000, Russia \\ 5 Kawatabi Field Science Center, Graduate School of Agricultural Science, Tohoku \\ University, 232-3 Yomogida, Naruko-onsen, Osaki, Miyagi 989-6711, Japan \\ ${ }^{6}$ Hakuba-Goryu Alpine Botanical Garden, Hakuba 399-9211, Japan \\ 7 Institute of Environmental Science, Hokkaido Research Organization, Sapporo \\ 060-0819, Japan \\ ${ }^{8}$ Botanic Garden, Field Science Center for Northern Biosphere, Hokkaido University, \\ Sapporo 060-0003, Japan. * Correspondence: kohnakamur@ gmail.com
}




\begin{abstract}
In the circumboreal region, plants often have extremely-wide species ranges. Lagotis minor-glauca species complex widespread from (sub)arctic Asia to Alaska, however, have two allied narrow endemics in northern Japan: a serpentine plant L. takedana endemic to the Yubari Mountains (Mt. Yubari) and a non-serpentine plant L. yesoensis endemic to the Taisetsu Mountains (Mt. Taisetsu). Elucidating their origins sheds light on drivers for secondary-speciation of widespread circumboreal plants. To infer phylogenetic distinctiveness of two narrow endemics with those related taxa, which contained 25 out of all the 29 species of the genus, chloroplast DNA (cpDNA), nuclear ribosomal (nrITS), two low copy nuclear gene (LCN) markers and genome-wide single-nucleotide polymorphism genotyping (MIG-seq) were used. In the result of cpDNA analyses, the Lagotis minor-glauca species complex formed a clade. Within the clade, L. yesoensis and a portion of $L$. glauca samples formed a subclade. However, monophyly of each of the four species was not supported. In the results of nrITS and two LCN analyses, L. takedana was monophyletic, while monophyly was not recovered for each L. yesoensis, L. glauca, and L. minor. Based on a Bayesian dating analysis using nrITS data, the age of the most recent common ancestor of L. takedana was Ma (95\% confidence interval: 0.05-1.75 Ma). Possible scenario is that an ancestral linage being adapted to serpentine soils migrated into the alpine habitat of Mt. Yubari, that was formed with mountain uplift by the early Pleistocene, and subsequently reproductively isolated from non-serpentine populations and speciated. The contrasting result of L. yesoensis, that was phylogenetically indistinct, is possibly explained by incorrect taxonomy, or alternatively, shallow history and incomplete lineage sorting. In Mt. Taisetsu, massive volcanic eruptions had occurred the Early Pleistocene and even after the last glacial period, suggesting that alpine plants have not migrated into and established populations in Mt. Taisetsu until very recently. To fully resolve the phylogeny of the three species L. yesoensis, L. glauca, and L. minor, further analyses using high resolution molecular markers are needed. The present study illustrated that two narrow endemics in northern Japan diverged from the widespread species include phylogenetically distinctive and indistinctive species, owing to historical orogeny and ecological factors.
\end{abstract}

Keywords alpine plants $\bullet$ endemic plants $\bullet$ serpentine soil $\bullet$ historical orogeny $\bullet$ Lagotis • molecular phylogeny $\bullet$ Hokkaido

\title{
Introduction
}

In the circumboreal region, plants often have extremely-wide species ranges. These plants are adapted to harsh but less competitive environmental having one of the most severe climates on Earth where plant can survive. Despite their extreme environmental harshness, the plant species diversity is minimum in the northern areas and decreases from the equator towards the poles (Schluter and Ricklefs 1993; Huston 1994; Rosenzweig 1995; Qian et al. 1998; Qian 1999), which may be due to less ecological variation in the periphery of the circumboreal region.

Some widespread species in the circumboreal region, however, have closely related species distributed extremely locally restricted ones (narrow endemics). Geographic range sizes can vary enormously even between widespread species and closely related species (Brown et al. 1996; Gaston and Chown 1999; Webb and Gaston 2003). Such interspecific variation in range size can be associated with geographical isolation, and may in part be due to the biological traits and ecological requirements of particular species (Cowling et al. 1994; Desmet and Cowling 1999; Médail and Verlaque 1997; Hedge and Ellstrand 1999; Lavergne et al. 2003; 2004; 2005). Since geographic isolation might provide barrier to gene flow, given that marginal populations of widespread species are more possible to be isolated one, they can play an important trigger in speciation and those might be a common way by which narrow endemics originate.

This process of plants in the circumboreal region is often induced by range shift in the Pleistocene. Since the origin of species in circumboreal regions during the climate cooling in the Pliocene (Murray 1995), their current distribution have been formed by expanded and retreated of habitat and population as a result of the cycle of glacier and inter-glacier periods of the Pleistocene (Abbott et al. 2000; Avise 2000; Hewitt 2000; Abbot 2008). The range contractions of widespread 
species have left isolated populations in marginal areas, leading to speciation of narrow endemics. Recent molecular studies have revealed that not only climatic change in the Pleistocene, but also historical orogeny have played an important role in major trigger of species diversity (e.g. Richardson et al. 2001; Hoorn et al. 2010; Favre et al. 2014; Liu et al. 2014; Wen et al. 2014); some plants in the circumboreal region, also distributed as well as high mountains in Northern Hemisphere (Hultén and Fries 1986). Climatic changes associated with historical orogeny can be served as fragmentation of the distribution ranges of species, which might lead to barrier to gene flow (Ren et al. 2016). This process can lead to allopatric divergence and ultimately speciation (Mayr 1963; Rice and Hostert 1993).

Ecological factors, such as divergent habitats, also play significant roles in speciation (Rundle and Nosil 2005). Adaptation to newly emerged niches can stimulate populations to diverge and become isolated; ecological speciation (Filatov et al. 2016). Therefore, speciation process cannot simply be recognized as climatic changes and historical orogeny, but also ecological factors (Rieseberg and Willis 2007). Evaluating the relative roles of climatic changes, historical orogeny, and ecological factors in plant diversification lead to a better understanding of evolutionary history of narrow endemics that sheds light on drivers for speciation of species.

Since, East Asia was not heavily glaciated during the Pleistocene (Frenzel et al. 1992), many arctic and alpine plants have been expanded their range in this region. The high mountains in central Japan represents the southernmost range limit of those. Specifically, one-third of the Japanese alpine plants are endemic to Japan with closely related arctic species, or have extremely wide distribution range in the Arctic (Shimizu 1982; 1983). In this study, we explored this issue in two Japanese alpine narrow endemics of Lagotis takedana Miyabe et Tatew. and L. yesoensis (Miyabe et Tatew.) Tatew. (Plantaginaceae). Lagotis takedana is a serpentine narrow endemics at Mt. Yubari, Hokkaido, Japan. Lagotis yesoensis is also a narrow endemic at Mt. Taisetsu, Hokkaido, Japan (Fig. 1). These narrow endemic species is distributed in northern Japan that located around the distribution range of two closely related widespread species, L. glauca Gaertn. and L. minor (Willd.) Standal.. Lagotis glauca Gaertn. found in Rebun Island and the mountain ranges of central Honshu (Yamazaki 1993), and also in the Kuriles, Kamchatka, the Aleutian, and Alaska (Takahashi 2015; Fig. 1). Lagotis minor is distributed from northeastern Russia to Alaska and the Yukon (Fig. 1). Key morphological characters separating these four species are summarized (Table 1): corolla color, lower lip shape/size, stamen-adnate position, anther color/size, filament length, and leaf shape. Taxonomic treatment of the two narrow endemics as independent species is basically accepted in Japan (Yamazaki 1981, 1993; Yonekura and Kajita 2003-; Ohashi 2017); however, several studies have proposed different taxonomic treatments (Table 2). Lagotis takedana is sometimes treated as an intraspecific taxon of $L$. glauca: subspecies takedana (Miyabe et Tatewaki) et Nosaka ex Toyokuni (Toyokuni 1960; Nosaka 1974; Toyokuni 1977) or variety takedana (Miyabe et Tatew.) Kitamu. (Kitamura and Murata 1957; Ohwi 1965, 1978). Lagotis yesoensis is sometimes treated as an intraspecific taxon of L. stelleri Turcz., a synonym of L. minor: variety yesoensis Miyabe et Tatew. (Miyabe and Tatewaki 1933; Ohwi 1965, 1978) or subspecies yesoensis (Toyokuni 1977), or alternatively treated as an intraspecific taxon of L. minor: variety yesoensis (Miyabe et Tatewaki) Toyok. (Toyokuni 1981). Furthermore, in the Plant List (2013) L. takedana and L. yesoensis are treated as "unresolved" species, and L. glauca is synonymized with $L$. minor despite the morphological differences (Vikulova 1995; Table 1). Morphology-based taxonomy of these species is not settled yet. Molecular phylogenetic analyses of Lagotis are limited, and of the above-mentioned species only L. glauca (from Commander Islands) and L. minor (from Alaska) have been studied and formed a clade based on combined nrITS and cpDNA data (Li et al. 2014).

In the present study, We aimed to resolve the phylogenetic relationships among L. takedana, $L$. yesoensis, L. glauca, and L. minor (as below indicated as the Lagotis minor-glauca complex) and to test the phylogenetic distinctiveness of the two narrow endemics, a serpentine endemics L. takedana and a non-serpentine endemics L. yesoensis. Furthermore, We reconstructed phylogeographic history of the Hokkaido endemics based on molecular dating and geological history. 


\section{Materials and methods}

\section{Taxon sampling}

Lagotis J.Gaertn. is a small genus of perennial herbs comprising approximately 29 species. This genus is mainly distributed in moist sandy and gravelly areas in the Qinghai-Tibetan Plateau, Himalayas, Pamir, Central Asian mountains, arctic and subarctic Asia (northwest Mongolia, northern Japan and Russia), Alaska and the Yukon (Lu 1992; Fig. 1). In this study using cpDNA and nrITS sequence, 25 species of Lagotis among about 29 species were included. Four species, $L$. uralensis Schischk., L. ikonnikovii Schischk., L. spectabilis Kurz., and L. blatteri O.E.Schulz, were not obtained or analyzed in the present study. However, our samples included species representing all the sections and series recognized by $\mathrm{Lu}$ (1992) and covered the entire geographic range of Lagotis from northeastern Russia to Alaska.

We collected samples of L. takedana, L. yesoensis, L. glauca and L. minor from wild populations and collections in botanical gardens and herbaria. Lagotis takedana grows in serpentine sites with strong winds and occasional landslides at Mt. Yubari. Only two populations are known for this species, in which a few patches comprising several thousand individuals (A. Sugano personal observation). We collected samples in both the populations. Lagotis yesoensis grows in moist sandy and gravelly areas at Mt. Taisetsu. There are seven populations known for this species, with scattered patches containing tens of thousands of individuals, and samples were collected from five populations. Lagotis glauca grows in alpine areas and lowlands in the high-middle latitudes with alpine-like climates. We collected samples from two populations in Rebun Island and one population at Mt. Avacha, Kamchatka. In Rebun Island, the number of individuals of this species is only about one thousand (A. Sugano personal observation). Lagotis minor grows in mossy, moss-lichen, open grass tundra on slopes in the northeastern Russia to Alaska and the Yukon; this species was not collected from wild populations but from herbarium collection (below). In field sampling, leaves were collected from approximately twenty plants, with at least a few meters between sampled individuals, in each population for a future population genetic study and a portion of the collection was used in the present phylogenetic study. Sampling in Mt. Yubari, Mt. Taisetsu, and Rebun Island was conducted with permission from the authorities because these taxa and areas are protected by law. Living collections of Botanic Garden, Hokkaido University and Hakuba Goryu Alpine Botanical Garden were used, i.e., one samples of $L$. takedana from Mt. Yubari, three samples of $L$. yesoensis from Mt. Taisetsu, and three samples of L. glauca from Mt. Hakuba. Additionally, herbarium specimens were utilized to cover the species ranges. Leaf fragments were carefully collected from specimens of L. glauca from the Kuriles (one from each Rasshua, Chirpoi, Urup, and Onekotan islands) and L. minor from Schmidt Peninsula of Sakhalin in the herbarium of Hokkaido University Museum (SAPS). All the samples are described in Table 3 and Table S1. Additionally, a specimen of L. kunawurensis (Royle ex Benth.) Rupr. from the Himalayan range were also sampled. Sequence data for the other 20 species were downloaded from GenBank. Wulfenia carinthiaca Jacq. was selected as an outgroup based on a previous phylogenetic analysis of Lagotis (Li et al. 2014). All the other samples are listed in Table S2. In monophyletic species, that was revealed in the previous study (Li et al. 2014), sequence data were downloaded for one sample per species (in $L$. integrifolia (Wild.) Schischk., L. integra W.W.Sm., L. alutacea W.W.Sm. L. brevituba Maxim, L. angustibracteata P.C.Tsoong \& H.P.Yang, L. decumbens Rupr., L. globosa Hook.f. and $L$. brachystachya Maxim.).

\section{DNA extraction, amplification, and sequencing}

Total genomic DNA was extracted from silica-dried leaf samples using the cetyltrimethyl ammonium bromide (CTAB) method (Doyle and Doyle 1990). The quality of extracted DNA was checked by agarose gel electrophoresis. Internal transcribed spacer region of nuclear ribosomal DNA (nrITS) and four chloroplast DNA regions (matK, rps16, trnG-trnS, trnL-F) used in the previous phylogenetic analysis of Lagotis (Li et al. 2014) were hired in the present study (Table S3).

In addition, low copy nuclear (LCN) gene markers were used for selected samples that were monophyletic in the present cpDNA analyses (Results). We first screened $8 \mathrm{LCN}$ markers that were used for other genera of Plantaginaceae, and $11 \mathrm{LCN}$ markers that have been applied to a broad 
range of angiosperm (Table S4). Fifteen out of the $19 \mathrm{LCN}$ markers did not amplify or showed multiple bands (Table S4). The other four LCN markers LCN20, LCN38, LCN46 (Mayland-Quellhorst et al. 2016) and Agtl (Naumann et al. 2011) were successfully amplified and utilized (Table S5). PCR amplification was performed in $20 \mu$ l total volume: $10 \mu \mathrm{l}$ of Taq DNA polymerase 2x master mix (Amplicon, Rødovre, Denmark), $0.8 \mu 1$ of each forward and reverse primers $(10 \mathrm{pmol} / \mu \mathrm{l}), 0.4 \mu \mathrm{l}$ of DMSO, $0.8 \mu \mathrm{l}$ of total DNA (ca. $20 \mathrm{ng} / \mu \mathrm{l}$ ) and $7.2 \mu \mathrm{l}$ of distilled water. The PCR cycle conditions were as follows: cpDNA: initial template denaturation for 4 min at $95{ }^{\circ} \mathrm{C}$; 25 cycles of $50 \mathrm{~s}$ at $94{ }^{\circ} \mathrm{C}, 40 \mathrm{~s}$ at $50{ }^{\circ} \mathrm{C}$, and $40 \mathrm{~s}$ at $72{ }^{\circ} \mathrm{C}$; a final extension for $10 \mathrm{~min}$ at $72{ }^{\circ} \mathrm{C}$. nrITS: 4 min at $95{ }^{\circ} \mathrm{C} ; 25$ cycles of $50 \mathrm{~s}$ at $94{ }^{\circ} \mathrm{C}, 40 \mathrm{~s}$ at $60^{\circ} \mathrm{C}$, and $40 \mathrm{~s}$ at $72{ }^{\circ} \mathrm{C} ; 10 \mathrm{~min}$ at $72{ }^{\circ} \mathrm{C}$. Agtl: 2 min at $94{ }^{\circ} \mathrm{C} ; 40$ cycles of $45 \mathrm{~s}$ at $96{ }^{\circ} \mathrm{C}, 30 \mathrm{~s}$ at $55^{\circ} \mathrm{C}$, and $1.5 \mathrm{~min}$ at $72{ }^{\circ} \mathrm{C} ; 7 \mathrm{~min}$ at $72{ }^{\circ} \mathrm{C}$. $L C N 20, L C N 38$ and $L C N 46: 2 \mathrm{~min}$ at $98{ }^{\circ} \mathrm{C}$; 45 cycles of $15 \mathrm{~s}$ at $98{ }^{\circ} \mathrm{C}, 30 \mathrm{~s}$ at $55^{\circ} \mathrm{C}$, and $30 \mathrm{~s}$ at $72{ }^{\circ} \mathrm{C} ; 5 \mathrm{~min}$ at $72{ }^{\circ} \mathrm{C}$. The PCR products were purified by isopropanol precipitation. The purified PCR products were amplified using ABI PRISM Big Dye Terminator v.3.1 (Applied Biosystems, Foster, CA, USA) with the same primers as those used for the PCR. Sequence reaction was performed in $20 \mu$ l total volume: $0.3 \mu \mathrm{l}$ of BigDye Terminater 3.1 Ready Reaction Mix 2.5 X, 3.85 $\mu \mathrm{l}$ of BigDye Terminater v1.1 \& v3.1 5 X Sequencing Buffer, $1 \mu \mathrm{l}$ of primer $(3.2 \mu \mathrm{M}), 13.85 \mu \mathrm{l}$ of distilled water and $1 \mu \mathrm{l}$ of PCR product. The condition of sequence reaction was as follow: initial template denaturation for $1 \mathrm{~min}$ at $96{ }^{\circ} \mathrm{C} ; 25$ cycles of $10 \mathrm{~s}$ at $96{ }^{\circ} \mathrm{C}, 5 \mathrm{~s}$ at $50{ }^{\circ} \mathrm{C}$ and 4 min at $60{ }^{\circ} \mathrm{C}$; a final extension for $4 \mathrm{~min}$ at $60^{\circ} \mathrm{C}$. DNA sequencing was performed on an ABI Prism 3730 DNA analyzer (Applied Biosystems). Automatic base-calling was checked manually using Fintch TV v.1.4 (Geospiza, Seattle, WE, USA) or Chromas 2.6.2 (http://technelysium.com.au/wp/chromas/). Multiple heterozygotic sites were found in the four LCN markers (note that L. takedana and $L$. glauca were diploid, L. minor included both diploid and tetraploid, and L. yesoensis has not been cytologically studied; Albach et al. 2018). To statistically estimate haplotypes, PHASE 2.1 (Stephens and Donnelly 2003), as implemented in DnaSP v5 (Librado and Rozas 2009), was used with default parameter settings. A posterior probability cutoff was set to 0.7 and below this, each ambiguous site was coded as missing data. Sequence alignment was conducted using ClustalX v.2.1 (Larkin et al. 2007) and then edited manually using SeaView v. 4.6.1 (Gouy et al. 2010).

\section{Genome-wide single-nucleotide polymorphism genotyping (MIG-seq) analysis}

We used a novel approach that was termed "multiplexed inter-simple sequence repeats (ISSR) genotyping by sequencing" (MIG-seq), which is a PCR-based procedure for single nucleotide polymorphism (SNP) genotyping using next-generation sequencing (Suyama and Matsuki 2015) to examine the phylogenetic structure the Lagotis minor-glauca species complex which was phylogenetically closely related based on sequence analysis (see Results).

The 1st PCR step was performed to amplify ISSR regions from genomic DNA with MIG-seq primer set-1 according to Suyama and Matsuki (2015).1st PCR amplification was performed in $7 \mu 1$ total volume: $3.5 \mu \mathrm{l}$ of 2x Multiplex PCR Buffer (Multiplex PCR Assay Kit Ver.2, Takara Bio, Kusatsu, Japan), $0.14 \mu \mathrm{l}$ of each 1st PCR primers $(10 \mu \mathrm{M}), 0.035 \mathrm{ul}$ of Multiplex PCR Enzyme Mix (Multiplex PCR Assay Kit Ver.2, Takara Bio), $1 \mu \mathrm{l}$ of total DNA (ca. 20ng/ $\mu \mathrm{l}$ ) and $0.225 \mu \mathrm{l}$ of distilled water. The $1 \mathrm{st}$ PCR cycle conditions were as follows: initial template denaturation for $1 \mathrm{~min}$ at $94{ }^{\circ} \mathrm{C} ; 30$ cycles of $30 \mathrm{~s}$ at $94{ }^{\circ} \mathrm{C}, 60 \mathrm{~s}$ at $38{ }^{\circ} \mathrm{C}$, and $60 \mathrm{~s}$ at $72{ }^{\circ} \mathrm{C}$; a final extension for $10 \mathrm{~min}$ at $72{ }^{\circ} \mathrm{C}$. The 1st PCR products were purified with AMPure XP beads (Beckman Coulter, Pasadena, CA, USA).The 1st PCR products from each sample were diluted 41 times with deionized water and used as the template of the 2nd PCR. 2nd PCR amplification was performed in $12 \mu$ l total volume: $2.0 \mu \mathrm{l}$ of diluted 1st PCR product, $2.4 \mu \mathrm{l}$ of 5x PrimeSTAR GXL Buffer (Takara Bio), $0.96 \mu$ of each dNTP, $0.24 \mu 1$ of PrimeSTAR GXL DNA polymerase (Takara Bio), $1.2 \mu 1$ of common forward primer and individual reverse primer $(2 \mu \mathrm{M})$, and $4.0 \mu \mathrm{l}$ of distilled water. The 2 nd PCR cycle conditions were as follows: 12 cycles of $10 \mathrm{~s}$ at $98{ }^{\circ} \mathrm{C}, 15 \mathrm{~s}$ at $54{ }^{\circ} \mathrm{C}$, and $60 \mathrm{~s}$ at $68{ }^{\circ} \mathrm{C}$. The size of each 2nd PCR products (libraries) were measured and visualized using a Microchip Electrophoresis System (MultiNA, Shimadzu, Kyoto, Japan) with the DNA-2500 Reagent Kit (MultiNA). The libraries from each 2 nd PCR products with those index were pooled in equimolar concentrations. The mixed libraries were purified with AMPure XP beads (Beckman Coulter) to reduce the salt concentration. Fragments of the library in the size range 300-800 bp were isolated using Pippin Prep 
DNA size selection system (Sage Science, Beverly, MA, USA). The final concentration was measured using a SYBR green quantitative PCR assay (library Quantification Kit; Clontech Laboratories, Mountain View, CA, USA). Finally, library was denatured using $\mathrm{NaOH}(0.2 \mathrm{~N})$ and mixed with $5 \%$ of Illumina-generated PhiX control libraries. Approximately $12 \mathrm{pM}$ of the library was used for sequencing on an Illumina MiSeq Sequencer (Illumina, San Diego, CA, USA), using a MiSeq Reagent Kit v3 (150 cycle, Illumina).

\section{Phylogenetic analyses}

To test for phylogenetic congruence between cpDNA and nrITS, the incongruence length difference test (Farris et al. 1994) was conducted using the partition homogeneity test with 100 replicates using PAUP* v.4.0a 150 (Swofford 2002). This test revealed significant heterogeneity between the data sets $(P<0.05)$, and analyses were therefore separately performed for cpDNA and nrITS data sets. Phylogenetic analyses were conducted using maximum parsimony (MP), maximum likelihood (ML), and Bayesian inference (BI).

Indels potentially have phylogenetic information. However, they often show high levels of homoplasy and can be difficult to align, especially when a wide range of taxa are sampled (Meseguer et al. 2014). Therefore, gaps were treated as missing data in this analysis. The MP analysis was performed with PAUP using heuristic searches of 1000 replicates with random taxon addition and tree bisection reconnection (TBR) branch swapping, with the MulTrees and steepest descent options on, and the MaxTrees option set to 10,000. Bootstrap support (BS; Felsenstein 1985) was estimated from 1000 replicates with random taxon addition and tree bisection reconnection branch swapping, with the MulTrees option off and the MaxTrees option set to 200. To perform ML and BI analyses, the best model of nucleotide substitution was selected with MrModeltest (Nylander 2004) using Akaike information criterion (AIC; Akaike 1974). The ML analysis was conducted with RAxML v.8.2.X. using 1000 rapid bootstrap analysis and subsequently searched for the best scoring ML tree in one program run (Stamatakis 2014). BI analysis was conducted using MrBayes 3.2.6 (Ronquist 2012). Analyses were run for 30 million generations, sampling every one thousand generations. Convergence and effective sample size (> 200 after burn-in) of all parameters were checked with Tracer v.1.6 (Drummond and Rambaut 2007) and then the first 3,000 trees were discarded as burn-in. The $50 \%$ majority rule consensus tree of all the post-burn-in trees and posterior probability (PP) was calculated. The MP, ML and BI trees were displayed using Figtree v.1.3.1 (Drummond and Rambaut 2007).

\section{Molecular dating analysis}

To discuss historical biogeography of Lagotis in Hokkaido, Bayesian molecular dating was conducted based on nrITS sequence data with BEAST v.1.7.5 (Drummond et al. 2012). The best model of nucleotide substitution as selected with MrModeltest was used and base frequencies were fixed to observed frequencies in the data (i.e., an empirical base frequency setting). An uncorrelated lognormal distribution model was applied for rate variation among lineages. Speciation birth death model was employed for the branching rates. The unweighted pair-group method of arithmetic averages (UPGMA) was used to construct a starting tree. The calibration point was the split between Lagotis and Wulfenia (Mean = 19.3 Ma, $95 \%$ highest posterior density [HPD] interval = 11.3-29.6 $\mathrm{Ma}$ ), as estimated in Li et al. (2014), and normal-distribution age prior was used with an initial value of 19.3, mean value of 19.3, and a standard deviation of 4.1 (95\% prior interval of 11.26-27.34). Analyses were run for 30 million generations, sampling every one thousand generations. Convergence and effective sample size (> 200 after burn-in) of all parameters were checked with Tracer and then the first 3,000 trees were discarded as burn-in. A maximum clade credibility tree was estimated with a posterior probability limit of 0.5 by TreeAnnotator ver. 1.5.4 (Drummond and Rambaut 2007), and visualized with FigTree.

\section{Data analysis of MIG-seq}

The SNP data obtained by MIG-seq were pre-processed using the FASTX-Toolkit (http://hannonlab.cshl.edu/fastx_toolkit/) enable low-quality reads removed by the 'quality_filter' 
option, using the settings of $\mathrm{q}=30$ and $\mathrm{p}=40$. Adapter sequence that these reads contained were removed using TagDust (Lassmann et al. 2009). To obtain SNP from the quality-filtered reads, Stacks v. 1.15 (Catchen et al. 2011) was used. The setting parameter using the 'ustacks' option was modified of Suyama and Matsuki (2015); maximum distance between stacks, the minimum depth of coverage required to create a stack, and maximum distance allowed to align secondary reads to primary stacks was set as 1, 5 and 1, respectively. In the 'cstacks' option, the parameter number of allowed mismatches between samples was set as 2 .

The resulting data set were checked using the NCBI nucleotide database using blastn in BLAST + 2.2.29 (ftp://ftp.ncbi.nih.gov/blast/executa- bles/LATEST/) with default settings and an $E$-value cutoff $10^{-10}$. Loci that had matched the organism that did not originated from plants were removed for further analysis.

We analyzed two different data set, for the Lagotis minor-glauca species complex and for the selected taxa of the Lagotis minor-glauca species complex that was not monophyletic based on sequence analysis (see Results). To exported genotype data, the 'population' option in Stacks was used. The exported genotype data were then processed using PLINK v.1.9 (Chang et al. 2015) and SNP loci with a minor allele frequency $<0.05$, missing individual rate $>0.6$, missing locus rate $>0.1$ and maximum observed heterozygosity rate $>0.7$ and deviation of Hardy-Weinberg equilibrium $(P<$ $0.01)$ were filtered out.

Principal coordinate analysis (PCA) was performed to examine phylogenetic structure using GENODIVE (Meirmans and Van Tienderen 2004) with the default setting parameters.

\section{Results}

\section{Phylogenetic positions of the Lagotis minor-glauca species complex in the genus based on cpDNA and nrITS}

The aligned length of cpDNA and nrITS was 2665 and $548 \mathrm{bp}$. The numbers of parsimony informative sites of cpDNA and ITS was $48(1.8 \%)$ and $46(8.4 \%)$. In this study, clades with PP $\geq 0.9$ and/or $\mathrm{BS}_{\mathrm{MP}} \geq 70 \%$ and/or $\mathrm{BS}_{\mathrm{ML}} \geq 70 \%$ were considered statistically supported. In either of cpDNA and nrITS markers, there was no topological incongruence among MP, ML and BI trees (data not shown). Therefore, only $\mathrm{BI}$ trees are presented with $\mathrm{BS}_{\mathrm{MP}}$ and $\mathrm{BS}_{\mathrm{ML}}$ (Fig. 2).

In the cpDNA phylogenetic tree (Fig. 2a), the clade of sect. Acaules (PP/ $\mathrm{BS}_{\mathrm{MP}} / \mathrm{BS}_{\mathrm{ML}}=0.99 / 100 \% / 100 \%$ ) was basal to the other species, that are all members of sect. Lagotis. Monophyly was supported neither for sect. Lagotis nor each of the three series Lagotis, Ramalanae, and Pharicae. Ser. Lagotis was divided into two clades, one including L. takedana, L. yesoensis, L. glauca, L. minor and other 11 species (0.99/72\%/-) and the other comprising the other three species (0.99/-/-). The former clade of ser. Lagotis was divided into two subclades, one including L. takedana, L. yesoensis, L. glauca, and L. minor with other four species (0.91/-/-) and the other including the other seven species (1/92\%/88\%). Phylogenetic relationship among $L$. takedana, L. yesoensis, L. glauca, L. minor, and the four species was not resolved. Lagotis takedana, L. yesoensis, L. glauca, and L. minor formed a clade (0.90/-/-), while monophyly of each of the four species was not supported. Within the clade, L. yesoensis and a portion of L. glauca samples (two from Kamchatka, one from Urup, three from Rebun, and three from Hakuba) formed a subclade (0.90/-/-). No geographic trend was recognized in the clustering of the L. glauca samples.

In the nrITS phylogenetic tree (Fig. 2b), sect. Acaules formed a clade $(1 / 97 \% / 96 \%)$ but the monophyly of sect. Lagotis was not supported. Within sect. Lagotis, a clade of ser. Ramalanae (1/96\%/97\%), one of ser. Pharicae (1/98\%/96\%), and two clades of ser. Lagotis were recognized: one including L. takedana, L. yesoensis, L. glauca and L. minor with other 11 species (1/-/71\%) and the other comprising the other three species $(1 / 93 \% / 79 \%)$. The relationship among L. takedana, $L$. yesoensis, L. glauca, L. minor and the 11 species was not resolved due to the low resolution of the tree. A clade of L. takedana, L. yesoensis, L. glauca, and L. minor, that was found in the cpDNA phylogeny, was not indicated. It should be noted that L. takedana formed a clade (1/95\%/89\%), while monophyly was not recovered for each L. yesoensis, L. glauca, and L. minor.

Phylogenetic relationships of the Lagotis minor-glauca species complex based on LCN gene 


\section{markers}

The present cpDNA analyses showed that the Lagotis minor-glauca species complex formed a monophyletic lineage. However, the resolution of the phylogenetic relationships among these four species was very low except that $L$. takedana was monophyletic in the nrITS analyses. Hence, LCN gene markers were also used to resolve the phylogeny of the four species. Lagotis kunawurensis was selected as an outgroup based on cpDNA tree of this study (Fig. 2a).

The aligned length of LCN38 and Agtl were 506 and $396 \mathrm{bp}$. The numbers of parsimony informative sites of $L C N 38$ and Agtl were $5(0.99 \%)$ and $3(0.76 \%)$. In each marker, there was no topological incongruence among MP, ML and BI trees (data not shown). Therefore, only ML trees are presented with $\mathrm{BS}_{\mathrm{MP}}$ and $\mathrm{PP}_{\mathrm{BI}}$ (Fig. 3).

In the LCN38 sequences, two paralogous copies (A and B) were recognized (Fig. 3a). It should be noted that the two paralogues were not found in all the samples; only paralogue A or B was amplified in a portion of samples of each four species, probably due to primer mismatch. In paralogue A, there was no sequence variation among the four species. On the other hand, paralogue B had comparatively large sequence variation, and monophyly of L. takedana was well supported, while for each of L. yesoensis, L. glauca and L. minor monophyly was not recovered. Similarly, two paralogous copies were recognized in the Agt1 sequences (Fig. 3b). Paralogue A and B in L. minor and paralogue B in L. yesoensis were not amplified. In L. takedana and L. glauca, only paralogue A or B was amplified in a portion of samples. In paralogue A, there was no sequence variation among L. takedana, L. glauca, and L. yesoensis. In paralogue B, monophyly of L. takedana was supported, while monophyly was not recovered for L. glauca.

The aligned length of LCN20, LCN46 were 677 and 567 bp. The numbers of parsimony informative sites of $L C N 2 O$ and $L C N 46$ were $3(0.44 \%)$ and $2(0.35 \%)$. In each $L C N 20$ and $L C N 46$, multiple paralogous copies per sample were recognized. However, ML phylogenetic analysis could not determine the copy numbers of LCN2O and LCN46 (tree not shown). Thus, further MP and BI analyses were not conducted and these two markers were not used anymore.

\section{Phylogenetic structure of the Lagotis minor-glauca species complex based on MIG-seq}

The MIG-seq analysis of the Lagotis minor-glauca species complex and of the selected taxa of the Lagotis minor-glauca species complex resulted in 552 and 519 SNPs, respectively, after filtering out the individuals and loci based on the thresholds of setting parameters as below. The variances of PCA explained by the first principle component (17.4\%) and the second one (13.9\%) were low, however, the result of PCA for the Lagotis minor-glauca species complex revealed L. takedana was clearly separated with L. yesoensis, L. glauca and L. minor (Fig. 4a), which was consistent with nrITS and two LCN phylogenetic trees. Compared with the results of cpDNA, nrITS and two LCN markers data, the phylogenetic structure of the Lagotis minor-glauca complex based on the MIG-seq data showed cluster of each species and geographic trends in detail. For the selected taxa of the Lagotis glauca-minor species complex (i.e. L. yesoensis, L. glauca and L. minor), the variances of PCA explained by the first principle component $(20.0 \%)$ and the second one $(8.7 \%)$ were low, however those revealed the genetic structure of the non-serpentine Lagotis minor-glauca species complex (Fig. 4b). Using the first principle component, the genetic structures revealed that L. glauca was separated with L. yesoensis and L. minor. Furthermore the three genetic structures was detected that L. glauca from the Kamchatka peninsula was located between L. yesoensis $-L$. minor and $L$. glauca from the Rebun lsland $\bullet$ Mt. Hakuba $\bullet$ the Kuriles. The second principle component also explained the consistency structure.

\section{Molecular dating analysis}

The Bayesian molecular dating based on nrITS estimated the age of the most recent common ancestor (MRCA) of L. takedana as $0.75 \mathrm{Ma}(95 \% \mathrm{HPD}$ interval $=0.05-1.75 \mathrm{Ma})$. This period corresponds to the early to late Pleistocene. 


\section{Discussion}

\section{Phylogenetic distinctiveness of narrow endemic species, $L$. takedana and $L$. yesoensis}

In the cpDNA phylogenetic tree, the Lagotis minor-glauca species complex formed a clade (Fig. 2a). The grouping of the Lagotis minor-glauca species complex reveled in this study is consistent with the morphology-based taxonomic ideas that these species are closely related (Table 2).

Monophyly of L. takedana was supported in the nrITS and two LCN phylogenetic trees and PCA based on MIG-seq (Figs. 2b; 3; 4a). Morphology-based taxonomy has variously treated L. takedana as an independent species, a variety/subspecies of $L$. glauca, or an unresolved taxon, as summarized in Table 2. The present nrITS and LCN trees and PCA of MIG-seq revealed that $L$. takedana was clearly distinguishable from $L$. glauca. Therefore, this study supports the taxonomic idea that $L$. takedana is an independent species.

In this study, L. yesoensis and a portion of $L$. glauca samples formed a subclade within a clade of the grouping of the Lagotis minor-glauca complex in the cpDNA phylogenetic tree (Fig. 2a); however, L. yesoensis and L. glauca were clearly distinguishable based on the PCA of MIG-seq (Fig. 4b). Moreover, there was no genetic differentiation between L. yesoensis and L. minor based on the PCA of MIG-seq (Fig. 4b). Our analyses of the MIG-seq data supported L. takedana was monophyletic, congruent with our results of nrITS and two LCN tree. However, although $L$. yesoensis and a portion of $L$. glauca samples formed a clade in the cpDNA tree, our analysese of the MIG-seq supported L. yesoensis and L. glauca was distinguishable. Given that only cpDNA data showed this incongruence and the relatively shallow of the divergent time of $L$. yesoensis and $L$. glauca (see Discussion), we suggested that incomplete lineage sorting may play a major role in the incongruence between cpDNA and MIG-seq data. MIG-seq is an effective method for genome-wide single-nucleotide polymorphism genotyping, thus, MIG-seq data from enough loci is possible to overcome incomplete lineage sorting owing to individual loci having different evolutionary histories. Taxonomy of $L$. yesoensis has been unclear; it has been recognized as an independent species, a subspecies/variety of $L$. stelleri (a synonym of $L$. minor), a variety of $L$. minor, or an unresolved taxon (Table 2). However, the monophyly of $L$. yesoensis was not recovered and $L$. yesoensis was not unambiguously distinguished from L. minor in the MIG-seq data. The result of phylogenetically indistinct $L$. yesoensis is possibly explained by (1) incorrect taxonomy, (2) hybridization with $L$. minor, or (3) incomplete linage sorting.

Concerning the first possible explanation, i.e., incorrect taxonomy, it was reported that $L$. yesoensis is morphological distinct from L. minor (Yamazaki 1981, 1993; Vikulova 1995; Ohashi 2017; Table 1). However, the present analyses did not separate these species. Lagotis minor is broadly distributed from northeastern Russia to Alaska and the Yukon. Previous morphological studies on L. minor examined portions of the entire species range ; Vikulova (1995) chiefly investigated Russian Far East samples. Morphological comparison of L. yesoensis with L. minor should cover the entire range of the two species in order to elucidate a degree of morphological overlap. Hybridization and introgression (Rieseberg and Soltis 1991; Rieseberg et al. 1996; Ferguson and Jansen 2002; Barber et al. 2007; Pirie et al. 2009; Jabaily and Sytsma 2010; Zhang et al. 2014) and incomplete lineage sorting (Mason-Gamer et al. 1995; Wendel and Doyle 1998; Comes and Abbott 2001; Linder and Rieseberg 2004; Willyard et al. 2009) do contribute to phylogenetic incongruence (Gurushidze et al. 2010). It is sometimes difficult to distinguish between these two possible reasons in phylogenetic incongruence (Wendel and Doyle 1998; Comes and Abbott 2001; Holder et al. 2001; Jakob and Blattner 2006; Holland et al. 2008). However, the distribution area of $L$. yesoensis currently do not overlap with those of $L$. minor, and therefore the probability of hybridization is considered very low. The second possible explanation seems to be the less probable one. Given that the populations in Mt. Taisetsu (i.e. "L. yesoensis") diverged from $L$. minor in a very recent time (see below), incomplete lineage sorting might be possible. However, our analysis based on MIG-seq data was inadequate because we used only two samples of $L$. minor and limited population. Thus, at this stage, the data are inconclusive about which explanation is more likely: incorrect taxonomy or incomplete linage sorting. Taxonomic reconsideration based on more intensive sampling, as discussed above, should be conducted. Also, further molecular analyses with 
rapidly evolving markers such as simple sequence repeats are needed to resolve incomplete linage sorting.

\section{Contrasting biogeographic history of L. takedana and L. yesoensis}

The present phylogeographic analyses revealed that L. takedana is phylogenetically distinct while $L$. yesoensis is not. Lagotis takedana and L. yesoensis has been reported that they are endemic to Mt. Yubari and Mt. Taisetsu respectively and there are geohistorical and environmental differences between these two mountains. Mt. Yubari is located in the Kamuikotan metamorphic belt and has serpentine sites (Fig. 1b; Gouchi 1983). Mt. Yubari was formed with mountain uplift by the early Pleistocene and its alpine environment was created through it (Shimizu 1999). On the other hand, Mt. Taisetsu is volcanic and was formed through repeated volcanic activities since the Pliocene and even after the last glacial period (Kokubutani et al. 1968; Wada 2007).

In this study, L. takedana represents a distinct species from the others Lagotis minor-glauca complex. Althought the phylogenetic relationship among the Lagotis minor-glauca complex was not resolved cleary, the complex formed a clade, indicating that L. takedana is a narrow endemic species derived from either the widespread L. glauca or L. minor. Elsewise, the MRCA of the Lagotis minor-glauca complex led to the speciation of L. takedana. In the molecular dating based on nrITS, it was estimated that L. takedana has the MRCA in the early to late Pleistocene (mean, $0.75 \mathrm{Ma}$; $95 \%$ confidence interval, 0.05-1.75 Ma). This period fits the time when Mt. Yubari was formed with mountain uplift and its alpine habitats became available. Mt. Yubari is one of typical examples of mountains with serpentine and limestone-derived soils (Horie 2000). In serpentine soils, high levels of endemism have been reported (Brady et al. 2005). Serpentine soil accumulates nickel and magnesium that give toxic effect to plants (Gabbrielli and Pandolfini 1984; Gabbrielli et al. 1990). Additionally, serpentine soils have low accumulation of phosphorus, nitrogen and potassium that are essential for plants (Nagy and Proctor 1997). Horie et al. (2000) reported that L. takedana accumulates nickel to high level and is tolerant to nickel toxicity. Therefore, L. takedana is adapted to serpentine soils. On the other hand, L. glauca is reported to have limited tolerance to serpentine soils by examining the distribution of the species in serpentine and non-serpentine sites in Mt. Hakuba (Hatano and Masuzawa 2008). Based on the present and these studies, possible scenario is that an ancestral linage being adapted to serpentine soils migrated into the alpine habitat of Mt. Yubari during the Pleistocene, and subsequently reproductively isolated from non-serpentine populations and speciated. Plants adapted to serpentine soils are called serpentine plants (Brooks 1987) and in Mt. Yubari many other endemics are serpentine plants, that are considered (but not proved with molecular phylogeny) to have been derived from non-serpentine progenitors, e.g., Primula yuparensis Takeda and P. sorachiana Miyabe et Tatew. (Primulaceae), Anthoxanthum pluriflorum (Koidz.) Veldkamp var. pluriflorum and A. pluriflourum var. intermedium (Hack.) Yonek. (Gramineae), and Viola yubariana Nakai and V. brevistipulata (Franch. et Sav.) W. Becker subsp. brevistipulata (Violaceae) (Sato 2007).

The age of L. yesoensis was not estimated because monophyly was not recovered for this species. However, the age of L. yesoensis seems to be very recent because the ancestral polymorphisms in the cpDNA data have been retained with a portion of L. glauca samples, although the age based on molecular dating analysis is unknown. In Mt. Taisetsu massive volcanic eruptions had occurred since the Early Pleistocene and even after the last glacial period (Wada 2007), suggesting that alpine plants did not migrate into and establish populations in Mt. Taisetsu until very recently. Shallow history of the alpine habitats in Mt. Taisetsu likely explains the lack of phylogenetic divergence between L. yesoensis and its progenitor (that is possibly L. minor based on the PCA of MIG-seq) due to incomplete linage sorting because incomplete linage sorting is observed at early stage of speciation (Knowles and Carstens 2007).

The migration route of L. takedana was not discussed because of the low resolution of the phylogenetic trees. Concerning the geographic origin of alpine plants in Hokkaido, Takahashi (2005) argued that Sakhalin and the Kuriles are two major routes via that arctic plants migrated to Hokkaido. Hidaka-Yubari alpine vegetation has connection with that of the Asian Continent via Sakhalin, while Taisetsu-Shiretoko alpine vegetation does with that of the North American Continent via the Kuriles 
(Tatewaki 1963, 1967). A phylogeograhic study on Pedicularis resupinata L. (Orobanchaceae) depicted that the same haplotypes were shared between Mt. Yubari and Sakhalin, and between Mt. Taisetsu and Kamchatka (Fujii 2003). However, the PCA of MIG-seq in this study depicted that $L$. yesoensis and L. minor from Sakhalin was not unambiguously distinguishable, suggesting that $L$. yesoensis was derived from the widespread L. minor, not from $L$. glauca. This indicates that $L$. yesoensis possibly migrated to Mt. Taisetsu via Sakhalin. To elucidate the migration route of $L$. takedana and L. yesoensis, population-level analyses using more nuclear gene loci or simple sequence repeat markers are needed.

Some Japanese endemic alpine plants evolved from arctic-alpine relatives that migrated southwards in the Pleistocene (e.g. Ikeda et al. 2012; DeChaine et al. 2013; Ikeda et al. 2014). However, given that the limited glaciation in East Asia during the Pleistocene (Hultén 1937), it is plausible that at least some endemics in Japan, were not recently derived from arctic-alpine plants but rather persisted in isolation for a prolonged period during the Pleistocene (Ikeda et al. 2014). Many Japanese alpine plants investigated by molecular analysis showed genetic differentiation between northern and central Japan (e.g. Senni et al. 2005; Ikeda and Setoguchi 2007; Ikeda et al. 2008; Aizawa et al. 2009; Ikeda and Setoguchi 2013), showing that populations in central Japan have persisted and experienced several cycles of cold and warm periods in the Pleistocene. However, our study showed that no genetic differentiation in L. glauca between Rebun Island and Mt. Hakuba, and even continuous genetic structure from central Japan to Kamchatka. Thus, an ancestral lineage of L. glauca in Japan may not been influenced by the Pleistocene climate change and long term isolation; their range expansion was during the recent glacial period.

In conclusion, contrasting biogeographic histories of two narrow endemics in closely related species illustrate the importance of effects of historical orogeny and ecological factors.

\section{Acknowledgements}

We thank Seiichiro Miyamoto for assistance in field sampling and all colleagues of the Plant ecology and Systematics laboratory of Hokkaido university who provided critical discussion. The present study was supported by the Mitsui \& Co. Environment Fund (R15-0067) and Grants-in-Aid for Scientific Research (16K18596).

\section{References}

Abbott RJ (2008) History, evolution and future of arctic and alpine flora: Overview. Pl Ecol Divers 1:129-133. doi:10.1080/17550870802460976

Abbott RJ, Smith LC, Milne RI, Crawford RM, Wolff K, Balfour J (2000) Molecular analysis of plant migration and refugia in the Arctic. Science :289:1343-1346. doi:10.1126/science.289.5483.1343

Aizawa M, Yoshimaru H, Saito H, Katsuki T, Kawahara T, Kitamura K, Kaji M (2009) Range-wide genetic structure in a north-east Asian spruce (Picea jezoensis) determined using nuclear microsatellite markers. J Biogeogr 36:996-1007. doi:10.1111/j.1365-2699.2008.02074.x

Akaike H (1974) A new look at the statistical model identification. IEEE Trans Automa Contr 19:716-723. doi:10.1109/TAC.1974.1100705

Albach DC, Martínez-Ortega MM, Delgado L, Weiss-Schneeweiss H, Özgökce F, Fischer MA (2008) Chromosome Numbers in Veroniceae (Plantaginaceae): Review and Several New Counts1. Ann Mo Bot Gard 95:543-566. doi:10.3417/2006094

Avise JC (2000) Phylogeography: the history and formation of species. Cambridge, MA, USA: Harvard University Press.

Barber JC, Finch CC, Francisco-Ortega J, Santos-Guerra A, Jansen RK (2007) Hybridization in Macaronesian Sideritis (Lamiaceae): evidence from incongruence of multiple independent nuclear and chloroplast sequence datasets. Taxon:74-88. doi:10.2307/25065737

Brady KU, Kruckeberg AR, Bradshaw HD Jr (2005) Evolutionary ecology of plant adaptation to serpentine soils. Annu Rev Ecol Evol Syst 36:243-266. doi:10.1146/annurev.ecolsys.35.021103.105730

Brooks RR (1987) Serpentine and its vegetation: a multidisciplinary approach. Dioscorides, Portland 
Brown JH, GC Stevens, DM Kaufman (1996) The geographic range: size, shape, boundaries, and internal structure. Annu Rev Ecol Syst 27:597-623. doi : 10.1146/annurev.ecolsys.27.1.597

Catchen JM, Amores A, Hohenlohe P, Cresko W, Postlethwait JH (2011) Stacks: building and genotyping loci de novo from short-read sequences. G3 (Bethesda) 1:171-182. doi:10.1534/g3.111.000240

Chang CC, Chow CC, Tellier LC, Vattikuti S, Purcell SM, Lee JJ (2015) Second-generation PLINK: rising to the challenge of larger and richer datasets. Gigascience 4:7. doi:10.1186/s13742-015-0047-8

Comes HP, Abbott RJ (2001) Molecular phylogeography, reticulation, and lineage sorting in Mediterranean Senecio sect. Senecio (Asteraceae). Evolution 55:1943-1962. doi:10.1554/0014-3820(2001)055[1943:MPRALS]2.0.CO;2

Cowling RM, Witkowski ETF, Milewski AV, Newbey KR (1994) Taxonomic, edaphic and biological aspects of narrow plant endemism on matched sites in mediterranean South Africa and Australia. J Biogeogr 21:651-664. doi:10.2307/2846038

DeChaine EG, Anderson SA, McNew JM, Wendling BM (2013) On the evolutionary and biogeographic history of Saxifraga sect. Trachyphyllum (Gaud.) Koch (Saxifragaceae Juss.). PLoS ONE 8: e69814. doi:10.1371/journal.pone.0069814

Desmet PG, Cowling RM (1999) Biodiversity, habitat and range-size aspects of a flora from a winter-rainfall desert in north-western Namaqualand, South Africa. Plant Ecol 142:23-33.

Doyle JJ, Doyle JL (1990) Isolation of plant DNA from fresh tissue. Focus 12:13-15

Drummond AJ, Rambaut A (2007) BEAST:Bayesian evolutionary analysis by sampling trees. BMC Evol Biol 7:214. doi:10.1186/1471-2148-7-214

Drummond AJ, Suchard MA, Xie D, Rambaut A (2012) Bayesian phylogenetics with BEAUti and the BEAST 1.7. Mol Biol Evol 29:1969-1973. doi:10.1093/molbev/mss075

Farris JS, Källersjö M, Kluge AG, Bult C (1994) Testing significance of incongruence. Cladistics 10:315-319. doi:10.1111/j.1096-0031.1994.tb00181.x

Favre A, Päckert M, Pauls SUet al (2015) The role of the uplift of the Qinghai-Tibetan Plateau for the evolution of Tibetan biotas. Biol Rev 90: 236-253. doi:10.1111/brv.12107

Felsenstein J (1985) Confidence limits on phylogenies: an approach using the bootstrap. Evolution 39:783-791. doi:10.1111/j.1558-5646.1985.tb00420.x

Ferguson CJ, Jansen RK (2002) A chloroplast DNA phylogeny of eastern Phlox (Polemoniaceae): implications of congruence and incongruence with the ITS phylogeny. Amer J Bot 89:1324-1335. doi:10.3732/ajb.89.8.1324

Filatov DA, Osborne OG, Papadopulos AS (2016) Demographic history of speciation in a Senecio altitudinal hybrid zone on Mt. Etna. Mol Ecol 25:2467-2481.doi: 10.1111/mec.13618

Frenzel B, Pécsi M, Velichko AA (1992) Atlas of paleoclimates and paleoenvironments of the Northern Hemisphere: Late Pleistocene-Holocene. Hungarian Academy of Sciences, Budapest

Fujii N (2003) Chloroplast DNA phylogeography of Pedicularis resupinata (Scrophulariaceae) in Japan. Acta Phytotax Geob 54:163-175. doi:10.18942/apg.KJ00004623223

Gabbrielli P, Pandolfini T, Vergnano O, Palandri MR (1990) Comparison of two serpentine species with different nickel tolerance strategies. Plant Soil 122:271-277

Gabbrielli R, Pandolfini $\mathrm{T}$ (1984) Effect of $\mathrm{Mg}^{2+}$ and $\mathrm{Ca}^{2+}$ on the response to nickel toxicity in a serpentine endemic and nickel-accumulating species. Physiol Plant 62:540-544. doi:10.1111/j.1399-3054.1984.tb02796.x

Gärtner I (1770) Observationes et descriptiones botanicae. Novi Comment Acad Sci Imp Petrop 14:531-537

Gaston KJ, SL Chown (1999) Geographic range size and speciation. In: A E Magurran, R M May (eds) Evolution of biological diversity. Oxford University Press, Oxford, pp 236-259

Gouchi N (1983) Kamuikotan mnetamorphic rocks in the kamuikotan gorge area, west of Asahikawa, Hokkaido. J Jpn Assoc Mineral Petrol Econ Geol 78:383-389. doi:10.2465/ganko1941.78.383 [In Japanese] 
Gouy M, Guindon S, Gascuel O (2010) SeaView version 4: a multiplatform graphical user interface for sequence alignment and phylogenetic tree building. Mol Biol Evol 27:221-224. doi:10.1093/molbev/msp259

Gurushidze M, Fritsch RM, Blattner FR (2010) Species-level phylogeny of Allium subgenus Melanocrommyum: Incomplete lineage sorting, hybridization and $\operatorname{trn} F$ gene duplication. Taxon 59: 829-840

Hatano H, Masuzawa T (2008) Serpentine soil environments and distribution of alpine plants in the Shirouma Mountain Range. Jpn J Ecol 58:199-204. doi:10.18960/seitai.58.3_199 [In Japanese, abstract in English]

Hedge SG, Ellstrand NC (1999) Life history differences between rare and common flowering plant species of California and the British Isles. Int J Plant Sci 160:1083-1091. doi:10.1086/314204

Hewitt GM. 2000. The genetic legacy of the Quaternary ice ages. Nature 405: 907-913. doi:10.1038/35016000

Holder MT, Anderson JA, Holloway AK (2001) Difficulties in detecting hybridization. Syst Biol 50 : 978-982. Doi : 10.1080/106351501753462911

Holland BR, S Benthin, PJ Lockhart, V Moulton, KT Huber (2008) Using supernetworks to distinguish hybridization from incomplete lineage sorting. BMC Evol Biol 8:202. doi:10.1186/1471-2148-8-202

Hoorn C, Wesselingh FP, Ter Steege Het al (2010) Amazonia through time: Andean uplift, climate change, landscape evolution, and biodiversity. Science 330: 927-931. doi:10.1126/science. 1194585

Horie K (2000) Distribution of ultrabasicolous plants in Hokkaido. J Phytogeogr Taxon 48:79-85 [In Japanese]

Horie K, Mizuno N, Nosaka S (2000) Characteristics of nickel accumulation in native plants growing in ultramafic rock areas in Hokkaido. Soil Sci Plant Nutr 46:853-862. doi:10.1080/00380768.2000.10409151

Hultén E (1937) Outline of the history of arctic and boreal biota during the quarternary period. Stockholm: Bokförlags aktiebolaget Thule.

Hultén E, Fries M (1986) Atlas of North European vascular plants north of the Tropic of Cancer. Koeltz Scientific

Huston MA (1994) Biological diversity: the coexistence of species on changing landscapes. Cambridge University Press, Cambridge

Ikeda H, Carlsen T, Fujii N, Brochmann C, Setoguchi H (2012) Pleistocene climatic oscillations and the speciation history of an alpine endemic and a widespread arctic-alpine plant. New Phytol 194:583-594. doi:10.1111/j.1469-8137.2012.04061.x

Ikeda H, Setoguchi H (2007) Phylogeography and refugia of the Japanese endemic alpine plant,

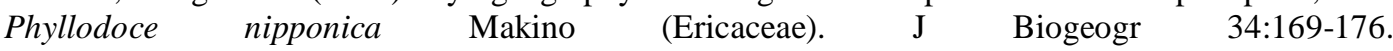
doi:10.1111/j.1365-2699.2006.01577.x

Ikeda H, Setoguchi H (2013) A multilocus sequencing approach reveals the cryptic phylogeographical history of Phyllodoce nipponica Makino (Ericaceae). Biol J Linn Soc 110: 214-226. doi:10.1111/bij.12116

Ikeda H, Senni K, Fujii N, Setoguchi H (2008) Consistent geographic structure among multiple nuclear sequences and cpDNA polymorphisms of Cardamine nipponica Franch. et Savat. (Brassicaceae). Mol Ecol 17:3178-3188. doi:10.1111/j.1365-294X.2008.03821.x

Ikeda H, Yakubov V, Barkalov V, Setoguchi H (2014) Molecular evidence for ancient relicts of arctic-alpine plants in East Asia. New Phytol 203:980-988. doi:10.1111/nph.12863

Jabaily RS, Sytsma KJ (2010) Phylogenetics of Puya (Bromeliaceae): placement, major lineages, and evolution of Chilean species. Amer J Bot 97:337-356. doi: 10.3732/ajb.0900107

Jakob SS, Blattner FR (2006) A chloroplast genealogy of Hordeum (Poaceae): long-term persisting haplotypes, incomplete lineage sorting, regional extinction, and the consequences for phylogenetic inference. Mol Biol Evol 23:1602-1612. doi:10.1093/molbev/ms1018

Kitamura S, Murata G (1957) New Names and New Conceptions adopted in our Coloured Illustrations of Herbaceous Plants of Japan (Sympetalae)*. Acta Phytotax Geobot:5-13 
Knowles LL, Carstens BC (2007) Delimiting species without monophyletic gene trees. Syst Biol 56:887-895. doi:10.1080/10635150701701091

Kokubutani M, Kobayashi T, Kim C, Kawauchi S (1968) 1:50,000 Geological map of Japan, Asahidake with explanatory text. Hokkaido Regional Development Bureau [In Japanese]

Larkin MA, Blackshields G, Brown NP, Chenna R, McGettigan PA, McWilliam H, Thompson JD (2007) Clustal $\mathrm{W}$ and Clustal $\mathrm{X}$ version 2.0. Bioinform 23:2947-2948. doi:10.1093/bioinformatics/btm404

Lassmann T, Hayashizaki Y, Daub C O (2009) TagDust - a program to eliminate artifacts from next generation sequencing data. Bioinform 25:2839-2840. doi.org/10.1093/bioinformatics/btp527

Lavergne S, Garnier E, Debussche M (2003) Do rock endemic and widespread plant species differ under the Leaf-Height-Seed plant ecology strategy scheme? Ecol Lett 6:398-404. doi:10.1046/j.1461-0248.2003.00456.x

Lavergne S, Thompson J D, Garnier E, Debussche M (2004) The biology and ecology of narrow endemic and widespread plants: a comparative study of trait variation in 20 congeneric pairs. Oikos 107 : 505-518. doi: 10.1111/j.0030-1299.2004.13423.x

Lavergne S, Debussche M, Thompson J D (2005) Limitations on reproductive success in endemic Aquilegia viscosa (Ranunculaceae) relative to its widespread congener Aquilegia vulgaris: the interplay of herbivory and pollination. Oecologia 142:212-220.

Librado P, Rozas J (2009) DnaSP v5: a software for comprehensive analysis of DNA polymorphism data. Bioinformatics 25:1451-1452. doi:10.1093/bioinformatics/btp187

Li GD, Kim C, Zha HG, Zhou Z, Nie ZL, Sun H (2014) Molecular phylogeny and biogeography of the arctic-alpine genus Lagotis (Plantaginaceae). Taxon 63:103-115. doi:10.12705/631.47

Linder CR, Rieseberg LH (2004) Reconstructing patterns of reticulate evolution in plants. Am J Bot 91:1700-1708

Liu JQ, Duan YW, Hao G, Ge XJ, Sun H (2014) Evolutionary history and underlying adaptation of alpine plants on the Qinghai-Tibet Plateau. J Syst Evol 52:241-249. doi:10.1111/jse.12094

Lu XF (1992) A study of Lagotis Gaertn. (Scrophulariaceae) in the Qinghai-Tibet Plateau. Acta Biol Plateau Sin 11:187-198

Nagy L, Proctor J (1997) Plant growth and reproduction on a toxic alpine ultramafic soil: adaptation to nutrient limitation. New Phytol 137:267-274

Naumann J, Symmank L, Samain MS, Müller KF, Neinhuis C, Wanke S (2011) Chasing the hare-Evaluating the phylogenetic utility of a nuclear single copy gene region at and below species level within the species rich group Peperomia (Piperaceae). BMC Evol Biol 11:357-376. doi:10.1186/1471-2148-11-357

Nosaka S (1974) The Phanerogam Flora of Mt. Yupari, Prov. Ishikari, Hokkaido, Japan. J Fac Sci Hokkaido Univ Ser V (Bot) 9:55-300

Nylander JAA (2004) MrModeltest v2. Program distributed by the author. Evolutionary Biology Centre, Uppsala University

Mason-Gamer RJ, Holsinger KE, Jansen RK (1995) Chloroplast DNA haplotype variation within and among populations of Coreopsis grandiflora (Asteraceae). Mol Biol Evol 12:371-381. doi:10.1093/oxfordjournals.molbev.a040228

Mayland-Quellhorst E, Meudt HM, Albach DC (2016) Transcriptomic resources and marker validation for diploid and polyploid Veronica (Plantaginaceae) from New Zealand and Europe. Appl Plant Sci 4:1600091. doi:10.3732/apps.1600091

Mayr E (1963) Animal species and evolution. Harvard University Press, Cambridge

Médail F, Verlaque R (1997) Ecological characteristics and rarity of endemic plants from southeast France and Corsica: implications for biodiversity conservation. Biol Conserv 80:269-281. doi:10.1016/S0006-3207(96)00055-9

Meirmans P G, Van Tienderen P H (2004) GENOTYPE and GENODIVE: two programs for the analysis of genetic diversity of asexual organisms. Mol Ecol Resour 4:792-794. doi: 10.1111/j.1471-8286.2004.00770.x

Meseguer AS, Sanmartín I, Marcussen T, Pfeil BE (2014) Utility of low-copy nuclear markers in phylogenetic reconstruction of Hypericum L.(Hypericaceae). Pl Syst Evol 300:1503-1514. doi: 10.1007/s00606-013-0977-5 
Miyabe K, Tatewaki M (1933) Contribution to the flora of northern Japan I. Trans Sapp Nat Hist Soc13:1-5

Murray D (1995) Causes of arctic plant diversity: origin and evolution. In: Chapin S, Korner C (eds) Arctic and alpine biodiversity. Springer, Heidelberg, pp 21-32

Ohashi H (2017) Plantaginaceae. In: Ohashi H, Kadota Y, Murata J, Yonekura K, Kihara H (eds) Wild Flowers of Japan. vol.5 Convolvulaceae Caprifoliaceae, Heibonsha, Tokyo, pp 76-77 [in Japanese]

Ohwi J (1965) Lagotis Gaerttn. In: Meyer FG, Walker EH (eds) Flora of Japan (in English), Smithsonian institution, Washington, pp 803

Ohwi J (1978) New edition revised and enlarged. Flora of Japan, Shibundo, Tokyo, pp 1204-1205 [In Japanese]

Pirie MD, Humphreys AM, Barker NP, Linder HP (2009) Reticulation, data combination, and inferring evolutionary history: an example from Danthonioideae (Poaceae). Syst Biol 58:612-628. doi:10.1093/sysbio/syp068

Qian H, Klinka K, Kayahara G J (1998) Longitudinal patterns of plant diversity in the North American boreal forest. Plant Ecol 138:161-178.

Qian H (1999) Spatial pattern of vascular plant diversity in North America north of Mexico and its floristic relationship with Eurasia. Ann Bot 83:271-283. doi:10.1006/anbo.1998.0816

Ren G, Mateo RG, Liu Jet al (2016) Genetic consequences of Quaternary climatic oscillations in the Himalayas: Primula tibetica as a case study based on restriction site-associated DNA sequencing. New Phytol 213:1500-1512. doi:10.1111/nph.14221

Rice WR, Hostert EE (1993) Laboratory experiments on speciation: what have we learned in 40 years. Evolution 47:1637-1653. doi:10.1111/j.1558-5646.1993.tb01257.x

Richardson JE, Pennington RT, Pennington TD, Hollingsworth PM (2001) Rapid diversification of a species-rich genus of neotropical rain forest trees. Science 293: 2242-2245. doi:10.1126/science. 1061421

Rieseberg LH, Soltis DE (1991) Phylogenetic consequences of cytoplasmic gene flow in plants. Evol Trends Pl 5:65-83

Rieseberg LH, Whitton J, Linder CR (1996) Molecular marker incongruence in plant hybrid zones and phylogenetic trees. Acta Bot Neerl 45:243-262

Rieseberg LH, Willis JH (2007) Plant speciation. Science 317: 910-914. doi:10.1126/science.1137729

Ronquist F, Teslenko M, Van Der Mark P, Ayres DL, Darling A, Höhna S, Huelsenbeck JP (2012) MrBayes 3.2: efficient Bayesian phylogenetic inference and model choice across a large model space. Syst Biol 61:539-542. doi:10.1093/sysbio/sys029

Rosenzweig ML (1995) Species diversity in space and time. Cambridge University Press, Cambridge.

Rundle HD, Nosil P (2005) Ecological speciation. Ecol Let 8:336-352. doi:10.1111/j.1461-0248.2004.00715.x

Sato K (2007) Geobotanical Study on the Alpine Vegetation of Hokkaido, Japan. Hokkaido university Press, Sapporo [In Japanese]

Schluter D, Ricklefs RE (1993) Species diversity: an introduction to the problem. In: Ricklefs R E, Schluter D (eds) Species diversity in ecological communities: historical and geographical perspectives. University of Chicago Press, Chicago, pp 1-10

Senni K, Fujii N, Takahashi H, Sugawara T, Wakabayashi M (2005) Intraspecific chloroplast DNA variations of the alpine plants in Japan. Acta Phytotaxon et Geobot 56:265-275

Shimizu T (1982) The new alpine flora of Japan in color, vol 1. Hoikusha, Osaka [In Japanese]

Shimizu T (1983) The new alpine flora of Japan in color, vol 2. Hoikusha, Osaka [In Japanese]

Shimizu C (1999) The gentle slopes due to landslide along the main divide of the Yubari mountains, Hokkaido, Japan. Komazawa Geography 35:115-122 [In Japanese]

Stamatakis A (2014) RAxML version 8: a tool for phylogenetic analysis and post-analysis of large phylogenies. Bioinform 30:1312-1313. doi:10.1093/bioinformatics/btu033

Stephens M, Donnelly P (2003) A comparison of bayesian methods for haplotype reconstruction from population genotype data. Am J Hum Genet 73:1162-1169. doi:10.1086/379378 
Suyama Y, Matsuki Y (2015) MIG-seq: an effective PCR-based method for genome-wide single-nucleotide polymorphism genotyping using the next-generation sequencing platform. Scientific reports 5 : 16963. doi:10.1038/srep16963

Swofford DL (2002) PAUP*. Phylogenetic analysis using parsimony (* and other methods). Version 4.0 b10. Sinauer Massachusetts: Sinauer

Takahashi H (2005) Migration routes of northen plants - Sakhalin and the Kuriles. Bunrui 5:89-97. doi:10.18942/bunrui.KJ00004651871 [In Japanese]

Takahashi H (2015) Phytogeography of the Kuril Islands, Hokkaido university Press, Sapporo, pp 305-306 [In Japanese]

Tatewaki M (1936) Taxonomic study of Alpine plants in Hokkaido. J Sapp Soc Agri Fores $131: 21-48$

Tatewaki M (1963) Alpine plants in Hokkaido. Sci Rep Tohoku Univ Ser IV (Biol) 29:165-188

Tatewaki M (1967) Distribution of alpine plants in northen Japan. Wright HE, Osburn WH (eds) Arctic and alpine environment, Indiana Univ Press, Bloomington

The Plant List (2013) Version 1.1 Published on the Internet. Avaliable at: http://wwwtheplantlist.org/, Accessed 1 January 2017

Toyokuni H (1960) On the Ultrabasicosaxicolous Flora of Hokkaido, Japan (8). J Geobot:10-13

Toyokuni H (1977) Index plantarum in regionibus alpinis Hokkaidoensibus sponte crescentium (4). J Asahikawa Univ 5:223-228

Toyokuni H (1981) A preliminary note on the floristic phytogeography of the alpine flora of Japan. J Fac Lib Arts Shinsyu Univ Nat Sci 15:81-96

Vikulova NV (1995) Lagotis Gaertn. In: Schischkin BK, Bobrov EG (eds), Flora of the USSR Volume XXII Solanaceae and Scrophulariaceae, Science publishers, United States of America, pp 439-445

Wada K (2007) Mt. Asahi. In: Katsui Y, Okada H, Nakagawa M (eds), Active volcano in Hokkaido, Hokkaido-Shinbunsha, Sapporo, pp 139-142 [In Japanese]

Webb T J, Gaston K J (2003) On the heritability of geographic range sizes. Am Nat 161:553-566. doi: $10.1086 / 368296$

Wendel JF, Doyle JJ (1998) Phylogenetic incongruence: Window into genome history and molecular evolution. In: Soltis DE, Soltis PS, Doyle JJ (eds) Molecular systematics of plants II: DNA sequencing, Kluwer, Dordrecht, pp 265-296

Wen J, Zhang J, Nie ZL, Zhong Y, Sun H (2014) Evolutionary diversifications of plants on the Qinghai-Tibetan Plateau. Front Genet 5: 4. doi:10.3389/fgene.2014.00004

Willyard A, Cronn R, Liston A (2009) Reticulate evolution and incomplete lineage sorting among the ponderosa pines. Mol Phylogenet Evol 52:498-511. doi:10.1016/j.ympev.2009.02.011

Yamazaki T (1981) Globulariaceae. In: Satake Y, Ohwi J, Kitamura S, Watari S, Tominari T (eds) Wild Flowers of Japan. Herbaceous Plants (including Dwarf Subshrubs) III Sympetalae, Heibonsha, Tokyo, pp 122 [in Japanese]

Yamazaki T (1993) Globulariaceae. In: Iwatsuki K, Yamazaki T, David EB, Ohba H (eds) Flora of Japan volume IIIa, Koudansha, Tokyo, pp 397-398

Yonekura K, Kajita T (2003-) BG Plants Japanese name-species name index (YList). Avaivable at: http://ylist.info, Accessed 5 April 2017 [in Japanese]

Zhang JQ, Meng SY, Allen GA, Wen J, Rao GY (2014) Rapid radiation and dispersal out of the Qinghai-Tibetan Plateau of an alpine plant lineage Rhodiola (Crassulaceae). Mol phylogenet Evol 77:147-158. doi : 10.1016/j.ympev.2014.04.013 


\section{Figure legends}

Fig. 1 (a) Distribution areas of the genus Lagotis and the four-studied species, L. takedana, L. yesoensis, L. glauca and L. minor. Dotted line, the genus Lagotis; red, L. takedana; orange, L. yesoensis; blue, L. glauca; green, L. minor. (b) Detail distribution areas of L. takedana, L. yeseoensis, and L. glauca in Hokkaido, Japan, which are indicated by red, orange and blue, respectively. The light green areas indicate the distribution of serpentine soils of the Kamuikotan metamorphic belts.

Fig. 2 Bayesian phylogenetic tree of 25 Lagotis species including Hokkaido endemic L. takedana and L. yesoensis and two allied species L. glauca and L. minor. (a) and (b) are based on cpDNA and nrITS, respectively. Lagotis takedana, L. yesoensis, L. glauca and L. minor are indicated in red, orange, blue, and green, respectively. Branches in bold are supported with $\mathrm{PP} \geq 0.9$ and/or $B S_{\mathrm{MP}} \geq 70$ and/or $\mathrm{BS}_{\mathrm{ML}} \geq 70$. Scale bar indicates 2.0 substitutions per site. For details of samples, refer Table3 and Online Resource 1.

Fig. 3 Maximum likelihood phylogenetic tree of the Lagotis minor-glauca species complex. (a) and (b) are based on LCN38 and Agt1, respectively. Lagotis takedana, L. yesoensis, L. glauca and L. minor are indicated in red, orange, blue, and green, respectively. Branches in bold are supported with $\mathrm{PP} \geq 0.9$ and/or $\mathrm{BS}_{\mathrm{MP}} \geq 70$ and/or $\mathrm{BS}_{\mathrm{ML}} \geq 70$. Scale bar indicates substitutions per site. For details of samples, refer Table3 and Online Resource 1.

Fig. 4 Genetic structure of the Lagotis minor-glauca species complex populations. Individual plots of PCA based on MIG-seq. Different populations from the same geographical localities present the same color but different markers. (a) is for the Lagotis minor-glauca species complex and (b) is for the species complex without L. takedana. Lagotis takedana, L. yesoensis and L. minor are indicated as red, orange and green markers, respectively. Lagotis glauca from Rebun Island, Mt. Hakuba, Kamchatka peninsula and the kuriles are indicated as cobalt, purple, blue and light blue markers, respectively. The percentage of total variation attributed to each axis is indicated. 
Table 1 Distribution area and key morphological characters of three Lagotis species in Japan and allied L. minor (Yamazaki 1981, 1993; Vikulova 1995;

Ohashi 2017)

\begin{tabular}{|c|c|c|c|c|c|c|c|}
\hline Species & Distribution & Corolla color & Lower lip shape/size & Stamen adnate position & $\begin{array}{l}\text { Anther } \\
\text { color/size }\end{array}$ & $\begin{array}{l}\text { Filament } \\
\text { length }\end{array}$ & Leaf shape \\
\hline L. takedana & $\begin{array}{l}\text { Mt. Yubari, } \\
\text { Hokkaido }\end{array}$ & $\begin{array}{l}\text { White or pale } \\
\text { lilac }\end{array}$ & $\begin{array}{l}\text { Lower lip lobes } \\
\text { lanceolate, as long as } \\
\text { upper lip }\end{array}$ & $\begin{array}{l}\text { Adnate to base of upper } \\
\text { corolla lip, much } \\
\text { shorter than upper lip }\end{array}$ & $\begin{array}{l}\text { Paler color, } \\
\text { ca. } 1.4 \times 1.8 \\
\mathrm{~mm}(\mathrm{~L} \times \mathrm{W})\end{array}$ & Ca. $0.5 \mathrm{~mm}$ & $\begin{array}{l}\text { Widely ovate } \\
\text { or elliptic }\end{array}$ \\
\hline L. yesoensis & $\begin{array}{l}\text { Mt. Taisetsu, } \\
\text { Hokkaido }\end{array}$ & Bluish purple & $\begin{array}{l}\text { Lower lip lobes narrowly } \\
\text { elliptic and rounded, } \\
\text { shorter than upper lip }\end{array}$ & $\begin{array}{l}\text { Adnate to middle of } \\
\text { upper corolla lip, } \\
\text { similar length to upper } \\
\text { lipcorolla }\end{array}$ & $\begin{array}{l}\text { Blackish } \\
\text { blue, ca. } 1.5 \mathrm{x} \\
1.7 \mathrm{~mm}\end{array}$ & Ca. $1 \mathrm{~mm}$ & $\begin{array}{l}\text { Ovate, elliptic } \\
\text { or oblong }\end{array}$ \\
\hline L. glauca & $\begin{array}{l}\text { The northern } \\
\text { Pacific rim. In } \\
\text { Japan, Rebun } \\
\text { Island and the } \\
\text { mountain ranges of } \\
\text { central Honshu }\end{array}$ & Bluish purple & $\begin{array}{l}\text { Lower lip lobes narrowly } \\
\text { oblong and rounded, } \\
\text { shorter than upper lip }\end{array}$ & $\begin{array}{l}\text { Adnate to base of upper } \\
\text { corolla lip, much } \\
\text { shorter than upper lip }\end{array}$ & $\begin{array}{l}\text { Dark purple, } \\
\text { ca. } 1.0 \times 1.5 \\
\mathrm{~mm}\end{array}$ & Ca. $0.5 \mathrm{~mm}$ & $\begin{array}{l}\text { Orbicular-ova } \\
\text { te to widely } \\
\text { ovate }\end{array}$ \\
\hline L. minor & $\begin{array}{l}\text { Northeastern } \\
\text { Russia to Alaska } \\
\text { and the Yukon }\end{array}$ & $\begin{array}{l}\text { Bluish or } \\
\text { whitish }\end{array}$ & $\begin{array}{l}\text { Lower lip lobes acute or } \\
\text { obtuse, slightly shorter } \\
\text { than upper lip }\end{array}$ & Exceeding upper lip & $\begin{array}{l}\text { Blue, 1-1.6 } \\
\text { mm wide }\end{array}$ & Ca. 2-4 mm & $\begin{array}{l}\text { Lanceolate to } \\
\text { elliptic }\end{array}$ \\
\hline
\end{tabular}


Table 2 Different taxonomic treatments of $L$. takedana, L. yesoensis, and L. glauca

\begin{tabular}{llll}
\hline Reference & L. takedana & L. yesoensis & L. glauca \\
\hline Gärtner (1770) & - & - & L. glauca \\
Miyabe and Tatewaki(1933) & L. takedana & L. stelleri var. yesoensis & - \\
Tatewaki (1936); Yamazaki (1981, 1993); Yonekura & L. takedana & L. yesoensis & L. glauca \\
and Kajita (2003-); Ohashi (2017) & L. glauca var. takedana & - & - \\
Kitamura and Murata (1957) & L. glauca subsp. takedana & - & - \\
Toyokuni (1960); Nosaka (1974) & L. glauca var. takedana & L. stelleri var. yesoensis & L.glauca \\
Ohwi (1965, 1978) & L. glauca subsp. takedana & L. stelleri subsp. yesoensis & - \\
Toyokuni (1977) & - & L. minor var. yesoensis & - \\
Toyokuni (1981) & unresolved & L. minor \\
The Plant List (2013) & unresolved & \\
\hline
\end{tabular}


Table 3 Collection locality, population, and number of samples analyzed in cpDNA, ITS, LCN and MIG-seq of the Lagotis minor-glauca complex from wild populations, botanic gardens, and herbaria. A dash indicates missing data.

\begin{tabular}{llll}
\hline Locality & Population & cpDNA & ITS \\
\hline
\end{tabular}

\section{L. takedana}

Fukitoshi, Mt. Yubari, Hokkaido, Japan

Daini Hourakuchi, Mt. Yubari, Hokkaido, Japan

$\begin{array}{lllll}\text { Yubari1 } & 3 & 3 & 3 & 12 \\ \text { Yubari2 } & 3 & 3 & 3 & 12\end{array}$

\section{L. yesoensis}

Takanegahara, Mt. Taisetsu, Hokkaido, Japan (ex-situ conservation at Botanic Garden, Hokkaido University)

Mt. Aka, Mt. Taisetsu, Hokkaido, Japan (ex-situ conservation at Botanic Garden, Hokkaido University)

Mt. Aka, Mt. Taisetsu, Hokkaido, Japan

A branch point of the trail between Mt. Hakuun and Mt. Koizumi, Mt. Taisetsu, Hokkaido, Japan

Mt. Koizumi, Mt. Taisetsu, Hokkaido, Japan

\section{L. glauca}

A hill 389 m asl., Rebun Island, Hokkaido, Japan

A hill 321 m asl., Rebun Island, Hokkaido, Japan

Mt. Rebun, Rebun Island, Hokkaido, Japan

Mt. Hakuba, Nagano, Japan (ex-situ conservation at Hakuba Goryu Alpine Plants Garden)

$\begin{array}{lcccc}\text { Taisetsu1 } & 2 & 2 & 2 & 3 \\ \text { Taisetsu2 } & 1 & 1 & 1 & 1 \\ \text { Taisetsu3 } & 2 & 2 & 2 & 12 \\ \text { Taisetsu4 } & 2 & 2 & 2 & 10 \\ \text { Taisetsu5 } & 2 & 2 & 2 & 12\end{array}$

$\begin{array}{lllll}\text { Rebun1 } & 2 & 2 & 2 & 12\end{array}$

Rebun2

Rebun3

Hakuba1

2

2


Mt. Hakuba, Nagano, Japan (ex-situ conservation at Hakuba Goryu Alpine Plants Garden)

Mt. Avacha, Kamchatka Peninsula, Russia

Rasshua Island, the Kuriles, Russia

Chirpoi Island, the Kuriles, Russia

Urup Island, the Kuriles, Russia

The Commander Island, Kamchatka Krai, Russia

Alaska, USA

\section{L. minor}

Southern Schmidt Peninsula, Sakhalin, Russia

Alaska, USA

$\begin{array}{lcccc}\text { Hakuba2 } & 2 & 2 & 2 & 10 \\ \text { Kamcha1 } & 2 & 2 & 2 & 11 \\ \text { Rasshua1 } & 1 & 1 & 1 & 1 \\ \text { Chirpoi1 } & 1 & 1 & 1 & 1 \\ \text { Urup1 } & 1 & 1 & 1 & 1 \\ - & 1 & 1 & - & - \\ - & - & 1 & - & -\end{array}$

Sakhalin1

2

2

22 

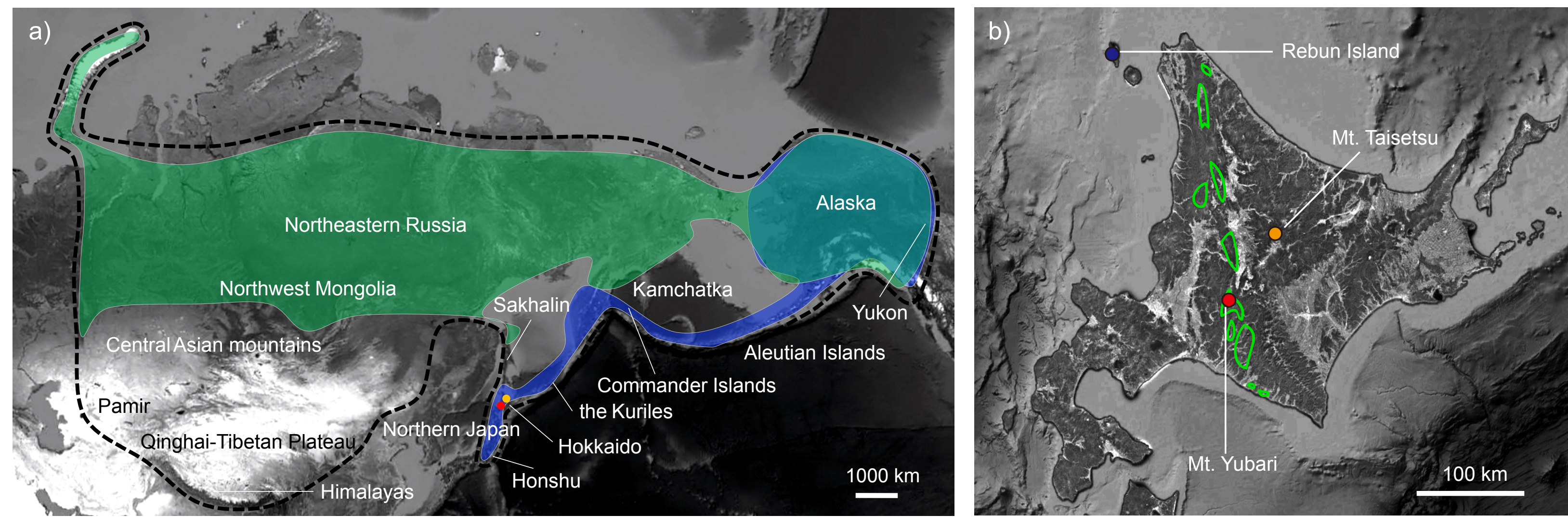
a) cpDNA

PPB//BSMP/BSML

2.0

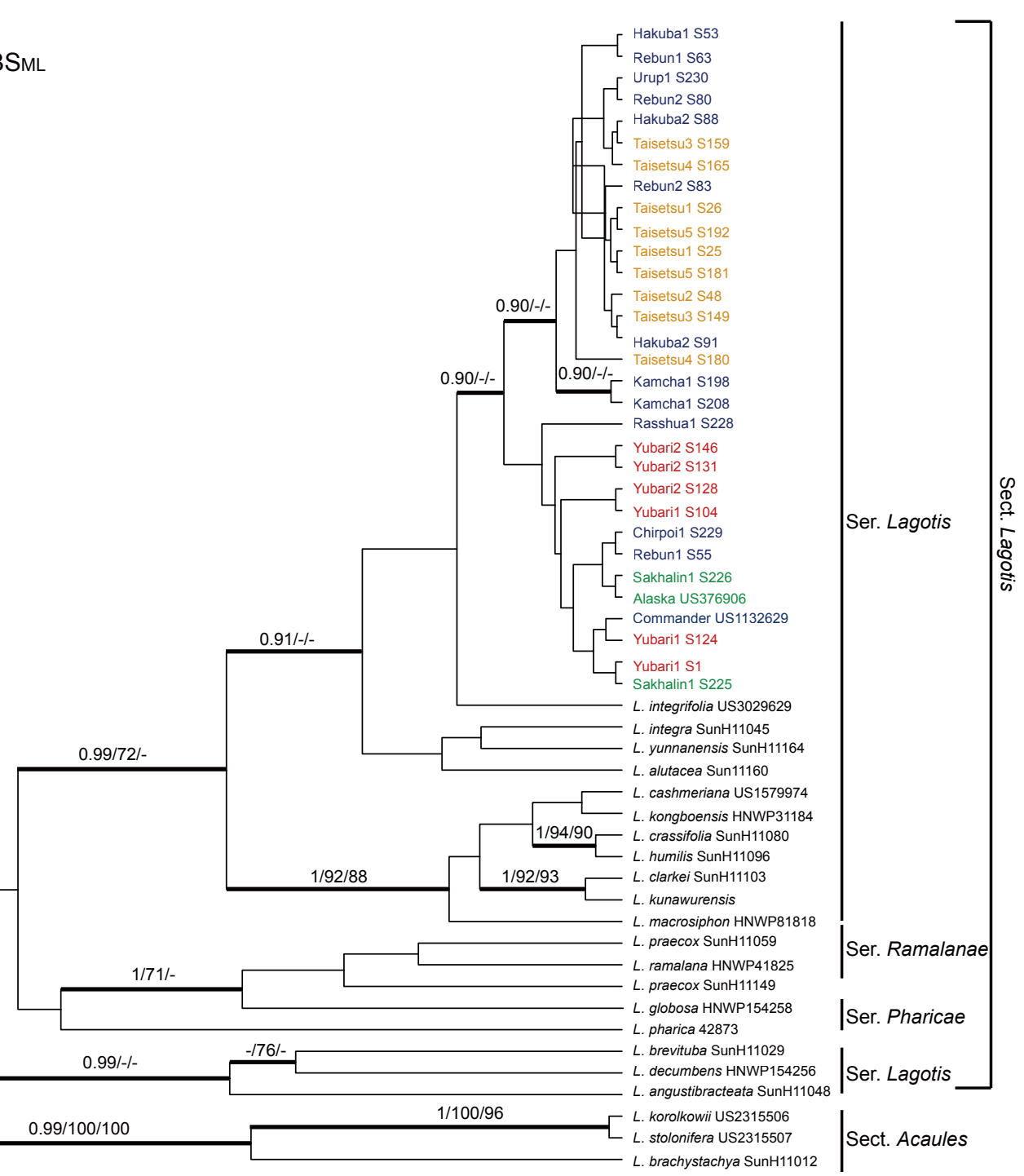

b) ITS

PPB//BSMP/BSML

2.0

Ser. Lagotis

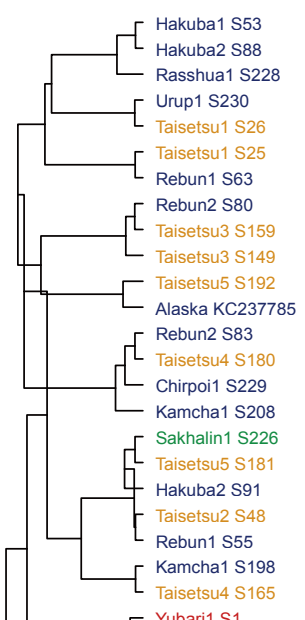

Yubari1 S1

1/95/89 [- Yubaril $\$ 104$

[ [ Yubari2 S131

0.95//-I- C Commander US1132629 Alaska US376900

$0.75(0.05,1.75)$ - Sakhalin 1 S225
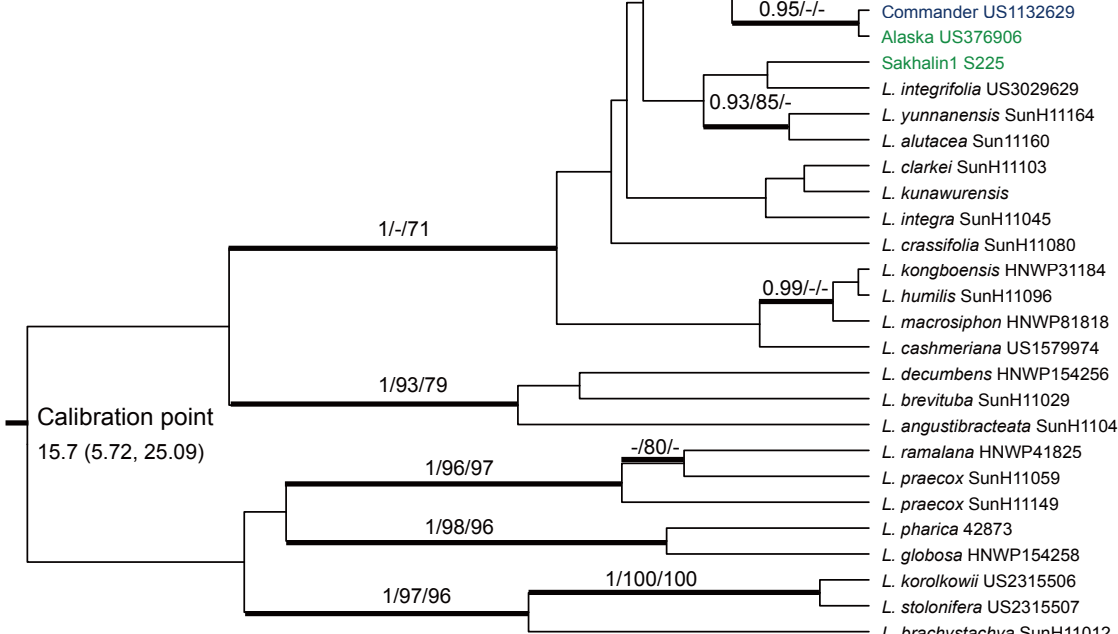

Ser. Ramalanae

Ser. Pharicae Sect. Acaules 


\section{a) $\operatorname{LCN} 38$}

$\mathrm{PPB} / \mathrm{BS} M P / B S M L$

$9.0 \mathrm{E}-4$

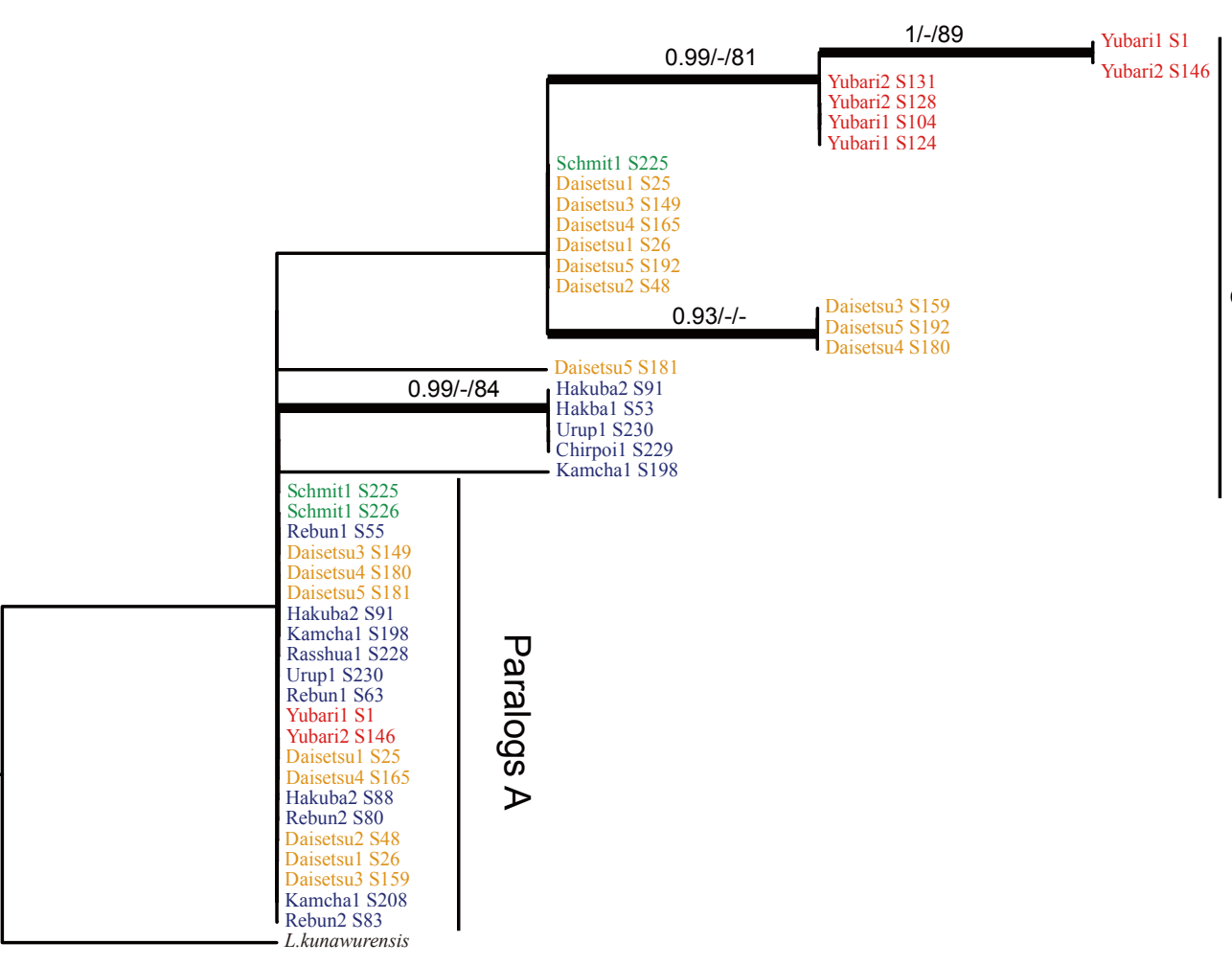

\section{b) agt1}

PPB/BSMP/BSML

$7.0 \mathrm{E}-4$

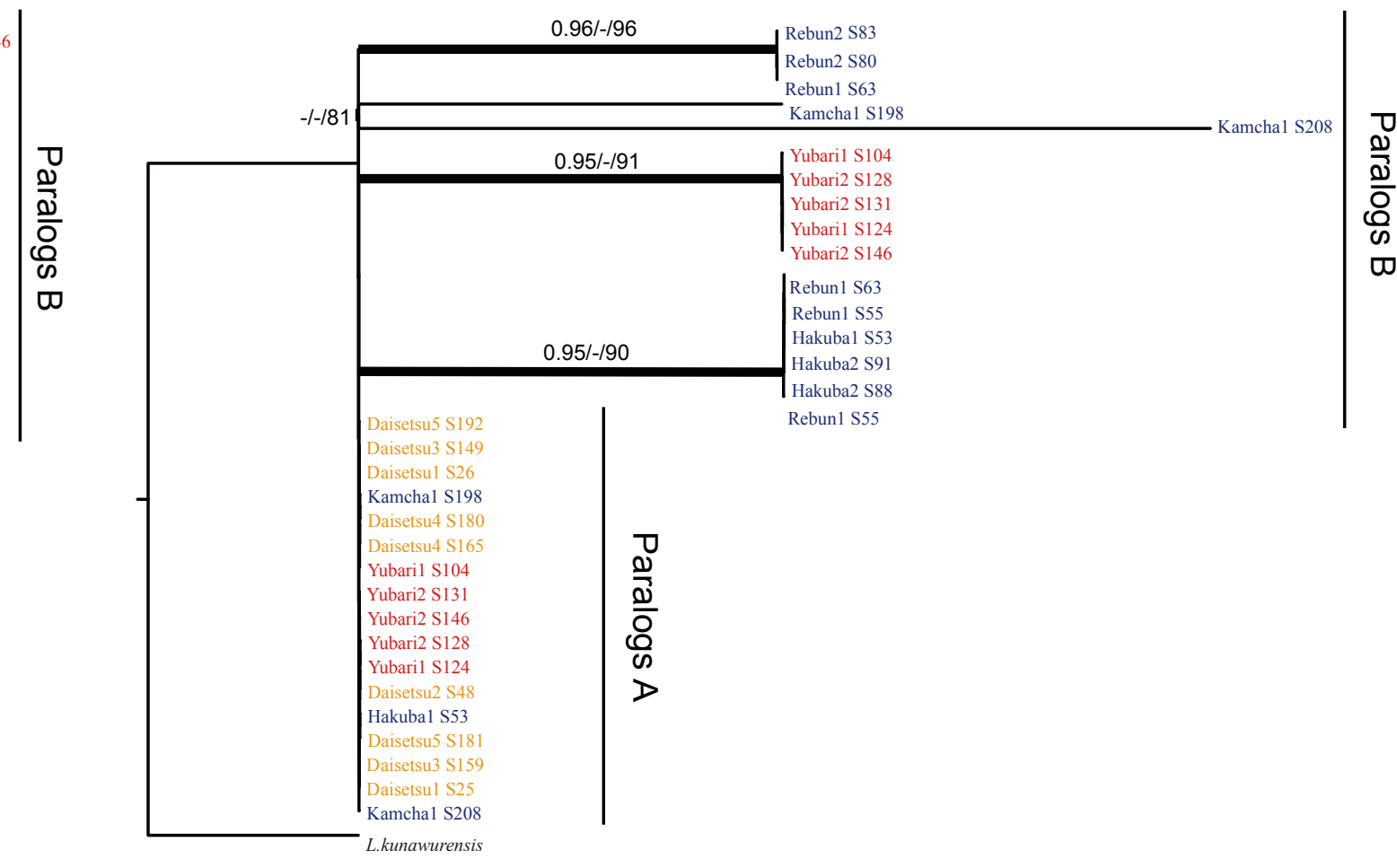




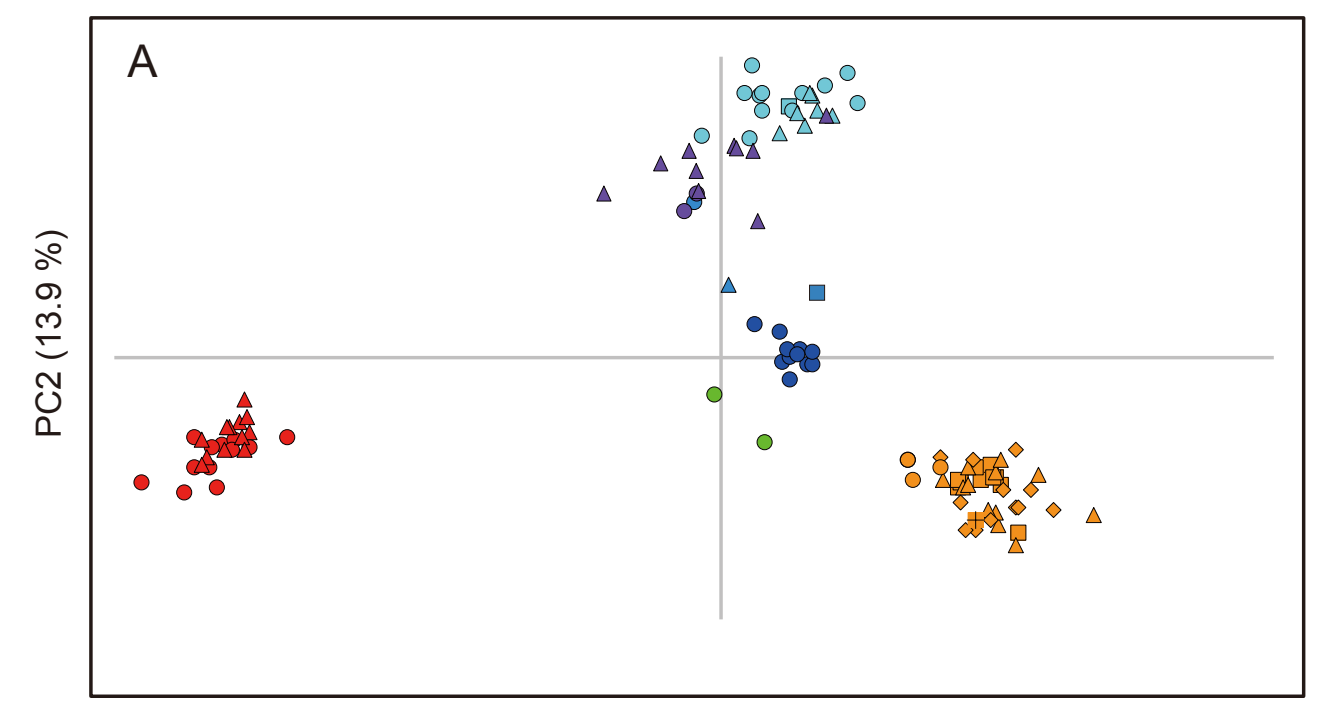

PC1 (17.4 \%)

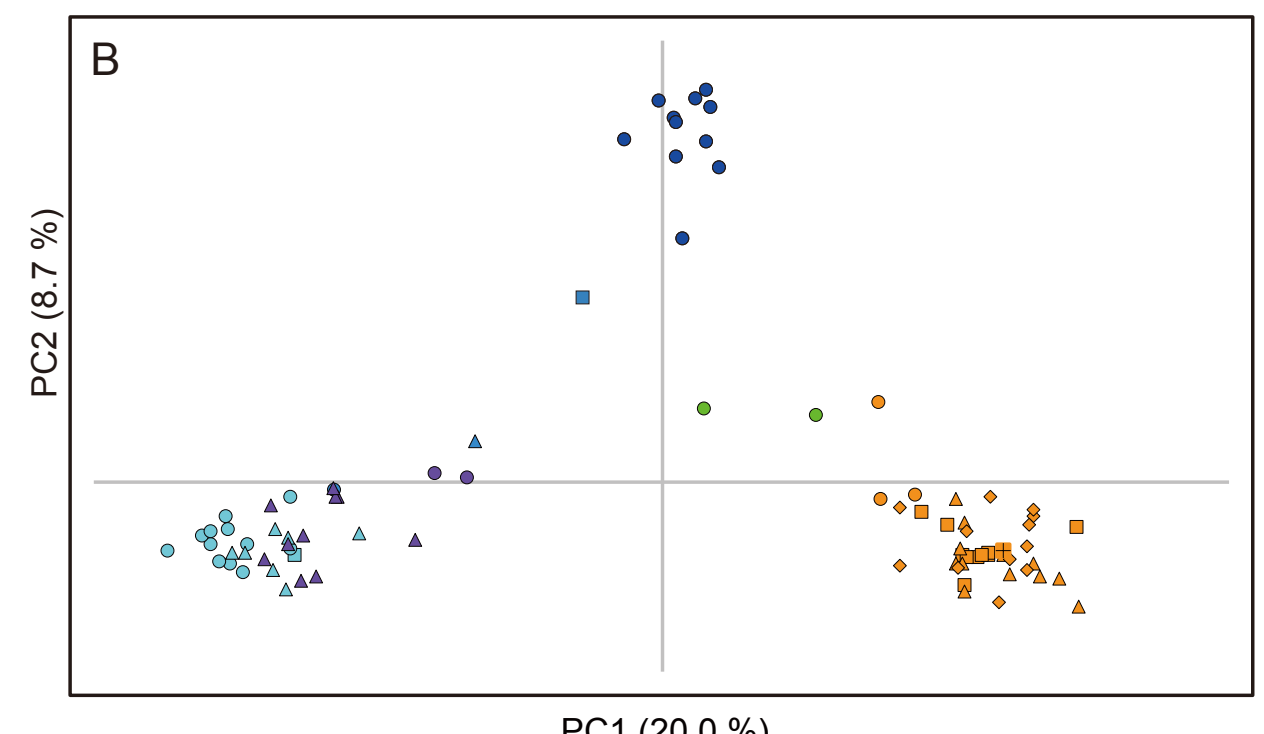

PC1 (20.0\%) 